\title{
Delincuencia patrimonial y jurisdicción militar durante el Sexenio absolutista
}

\section{Patrimonial delinquency and military jurisdiction during the absolutist Sexenio}

\author{
Pedro ORTEGO GIL \\ Catedrático de Historia del Derecho \\ Universidad de Santiago de Compostela \\ pedro.ortego@usc.es
}

Recibido: 4 de diciembre de 2012

Aceptado: 13 de febrero de 2013

\section{RESUMEN}

Tras la guerra contra el ejército napoleónico se incrementó la delincuencia patrimonial en zonas rurales y caminos. Para la aprehensión y castigo de los salteadores y bandidos Fernando VII dictó medidas, siguiendo el esquema de 1784, que favorecieron la intervención de la jurisdicción militar. Los consejos de guerra permanentes juzgaron a estos delincuentes con sujeción a las disposiciones militares y castigándoles con gran dureza.

PALABRAS CLAVE: Consejos de guerra, delincuencia patrimonial, jurisdicción militar, robos.

\begin{abstract}
After the war against the army of Napoleon increased the delinquency heritage in rural zones and ways. For the apprehension and punishment of the highwayman and bandits, Fernando VII dictated measures, following the diagram of 1784 , that favored the intervention of the military jurisdiction. The permanent councils of war judged to these criminals with subjection to the disposals military and punishing them with big hardness.
\end{abstract}

KEYWORDS: Councils of war, delinquency heritage, military jurisdiction, thefts.

\section{RÉSUMÉ}

Après la guerre contre l'armée napoléonienne la délinquance patrimoniale dans les zones rurales et les chemins augmenta. Afin de faciliter la capture et la punition des voleurs de chemins et bandits Ferdinand VII décréta de nouvelles mesures, en suivant le schéma de 1784, qui favorisèrent l'intervention de la juridiction militaire. Les conseils de guerre permanents jugèrent ces délinquants en les soumettant aux normes militaires et en les punissant avec une grande dureté.

MOTS CLÉ : Conseil de guerre, délinquance patrimoniale, juridiction militaire, vols.

\section{ZUSAMMENFASSUNG}

Nach dem Krieg gegen die Napoleonische Armee verstärkte sich in ländlichen Räumen und auf Landstraßen die die Vermögensdelikte betreffende Kriminalität. Für die Ergreifung und Bestrafung von Straßen- 
räubern/Wegelagerern und Banditen schrieb Fernando VII. Maßnahmen vor, die dem Schema von 1784 folgten und das Einschreiten der Militärjurisdiktion begünstigten. Diese ständigen Kriegsgerichte/Standgerichte urteilten über die Kriminellen nach militärischen Anordnungen und mit großer Härte.

SCHLÜSSELWÖRTER: Standgericht, Kriegsgericht, Vermögensdelikte, Militärjurisdiktion, Raub.

SUMARIO: 1. Los antecedentes de Carlos III y Carlos IV. 2. Las medidas legislativas tras la guerra. 3. La actuación de los consejos de guerra de Castilla la Nueva y de Valencia y Murcia. 4. Conflictos jurisdiccionales. 5. A modo de conclusión.

\section{Los antecedentes de Carlos III y Carlos IV}

La delincuencia patrimonial organizada en gavillas y partidas comenzó a constituir un grave problema desde los últimos decenios del siglo XVIII. En grupos más o menos numerosos, y dotados de armas de fuego, perpetraban sus delitos en zonas geográficas delimitadas, atacando especialmente en los caminos o en zonas aledañas a las poblaciones. Para la represión de este tipo de delincuencia no bastaban los medios tradicionales, como por ejemplo los alcaldes y cuadrilleros de la Hermandad. Fue necesario destinar tropas para su persecución, detención y, en ocasiones, exterminio.

La Instrucción del 29 de junio de 1784 determinaba los medios militares para perseguir a estos grupos de bandidos ${ }^{1}$. Disposición sobre la que otras posteriores volvieron a insistir en su cumplimiento. No solo se encomendaba su represión a la fuerza militar, sino que se otorgaba a la jurisdicción militar el conocimiento de las causas de aquellos malhechores aprehendidos por ella bajo determinadas condiciones ${ }^{2}$. Sin entrar en los pormenores acerca de las atribuciones encomendadas a los capitanes generales y sobre la formación de estas partidas militares, la determinación de la jurisdicción era clara. En sus artículos 8, 9 y 10 concretaba los ámbitos personal y material, la jurisdicción y los trámites procesales, así como las penas. De acuerdo con el primer artículo citado, esta disposición se dirigía contra bandidos, contrabandistas y salteadores, mientras que el segundo menciona a bandidos y contrabandistas, y último habla de contrabandistas y malhechores. Bajo tan vagas denominaciones, salvo en el caso de los contrabandistas, al final se incluía cualquier delincuente que cometiera delitos de naturaleza patrimonial. No bastaba con esta enumeración, pues era

\footnotetext{
${ }^{1}$ Tiene como antecedentes inmediatos los RR.DD. de 2 y 30 de abril de 1783, en Novísima Recopilación, 12, 10, 10. Para comprender su promulgación y primeros años de vigencia, José Miguel Palop Ramos, «La militarización del orden público a finales del reinado de Carlos III. La Instrucción de 1784», Revista de Historia Moderna, 22, 2004, pp. 453-486.

${ }^{2}$ Acerca del marco histórico normativo de esta jurisdicción en el Antiguo Régimen, Emiliano González Díez, «De la justicia penal militar: notas sobre el régimen jurídico-normativo hasta la época constitucional», Estudios sobre el ordenamiento jurídico español. Libro conmemorativo del X aniversario de la Facultad de Derecho, Burgos, 1996, pp. 775-794.
} 
preciso que los mismos hubieran sido perseguidos por las partidas militares destinadas expresamente a su aprehensión por orden de la autoridad militar. En este punto había que introducir un nuevo matiz, pues no todos los perseguidos por la tropa quedarían bajo la jurisdicción militar, al concurrir como requisito sine qua non la resistencia armada activa - con fuego o arma blanca-o haber concurrido con quienes la hicieron. Para los supuestos, implícitamente residuales, porque la tropa actúa como auxiliar de las jurisdicciones no castrenses y sin orden de la autoridad militar, se dispuso que «corra la administración de justicia por la jurisdicción a quien pertenezca el reo o reos aprehendidos, aunque haya habido resistencia» (art. 8). Por tanto, aunque la resistencia tiene importancia, es crucial que la partida militar perseguidora actuara comisionada por los capitanes o comandantes generales.

La pena prevista para los que hicieran resistencia armada a la tropa perseguidora era la de muerte si hubieran hecho fuego o usado armas blancas; y, en caso de que, sin hacerla, «concurrieron en la función», serían destinados por diez años a presidio. En los supuestos que he denominado residuales, la pena vendría determinada por la legislación civil o hacendística. No obstante, si en estos casos se hubiera realizado resistencia, el reo recibiría el doble centenar de azotes.

El consejo de guerra de oficiales estaría presidido por uno de graduación, designado por el capitán o comandante de la provincia ${ }^{3}$. Quedando estructurado con sujeción a las Ordenanzas militares. El principio básico bajo el que debía actuar el consejo de guerra era que «se administre pronta justicia en los delitos que van referidos, para que el escarmiento de unos sirva de freno a los demás». Para tal menester, debía comunicarse inmediatamente a la máxima autoridad militar de la provincia la aprehensión «y sus circunstancias, para que en caso de haber hecho resistencia a la tropa, mande formarles luego el proceso, y sentenciarles por el consejo de guerra de oficiales»; o, en su caso, la puesta de los delincuentes a disposición de la jurisdicción ordinaria -ladrones y malhechores- o de rentas -defraudadores-. Para la pronta resolución de estas causas criminales ordinarias o hacendísticas, los militares debían prestar toda su colaboración «para el más pronto y debido castigo».

En los supuestos de resistencia que quedaban bajo el prisma de la jurisdicción castrense, las condenas de muerte y de presidio debían consultarse, antes de su ejecución, al rey a través de la vía reservada de Guerra con el fin de obtener el plácet regio. No obstante, en el supuesto de que las causas criminales fueran competencia de la justicia ordinaria o de rentas y al tiempo de sentenciarlas se decretara la libertad,

\footnotetext{
${ }^{3}$ Sobre los consejos de guerra ordinario y de oficiales generales, Lázaro Dou i Bassols, Instituciones de Derecho público general de España, Madrid, 1800, tomo II, pp. 363-369. Por supuesto, Félix Colón de Larriátegui, Juzgados militares de España y sus Indias, Madrid, 1817 (6ª), en particular el tomo III para lo que aquí se trata, y sobre «el modo de substanciar los procesos de los malhechores que han de ser juzgados en consejo permanente de guerra compuesto de oficiales» (pp. 177-181). Véase también, tomo I, pp. 140-141, sobre la competencia del consejo de guerra permanente de Castilla la Nueva en materia de robos en la Corte y su rastro.
} 
el artículo 10 establecía una prevención que evidencia la preeminencia de la autoridad militar si hubieran sido apresados por la tropa: «no procederán a ponerlas en libertad sin dar antes aviso al capitán, o comandante general de la provincia, para que la tropa que los arrestó vea si tiene que pedir contra ellos, o encuentra algún inconveniente en su soltura; y en caso de hallarlo, lo expondrá al mismo Tribunal, y también al Rey por la vía reservada de Guerra, para que resuelva lo que tuviere por conveniente antes de ponerse a los reos en libertad». Si no hubiera objeción alguna, se les soltaría «con apercibimiento de que tomen algún modo honesto de vivir, para no dar lugar a que se sospeche mas de sus personas $\rangle^{4}$.

Desde el inicio se plantearon conflictos entre la jurisdicción ordinaria y la militar. Mientras los facinerosos, malhechores y contrabandistas continuaron actuando. Lo cual requirió nuevas disposiciones que zanjaran las disputas jurisdiccionales fijando reglas claras para la determinación del conocimiento de las causas contra malhechores apresados por partidas militares 5 . En virtud de las Reales órdenes 30 de marzo de 1801 y 10 de abril de 1802 que quedaron fundidas en Novísima Recopilación, 12, 17, 8 , se estableció que «todos los reos que se aprehendan por las partidas de tropa, comisionadas en su persecución, y sean salteadores de caminos, se pongan a disposición de los respectivos capitanes y comandantes generales, para que procediendo militarmente contra ellos, se les juzgue en consejo de guerra ordinario de oficiales con asistencia del asesor, que al efecto nombrarán dichos superiores gefes, y con inhibición de todo otro tribunal», con obligación de consultar las sentencias al rey por la vía reservada de guerra para su aprobación; pero «si el reo fuese contrabandista, y no resultase inculcado en otro delito que el de defraudador de la Real Hacienda, se entregará con las armas, caballos y demás efectos aprehendidos al subdelegado de rentas, para que por él sea juzgado como corresponde». Con el mismo objeto de resolver por punto general otros conflictos entre autoridades, quedó dispuesto que «todos los salteadores de caminos y sus cómplices que sean aprehendidos por la tropa dentro de las capitales de las provincias y demás poblaciones, quedarán sujetos al referido juicio militar, del mismo modo que los que lo fuesen en los caminos y despoblados por las relaciones que tienen entre sí esta clase de bandidos; pero que los demás reos que no sean de esta especie, pertenecerán a la justicia ordinaria, al menos que hagan resistencia a la tropa; en cuyo caso se procederá con arreglo a la Real instrucción de 29 de junio de 1784». Se reiteraba, por tanto, la delimitación de la competencia jurisdiccional, sobre todo, tratándose de salteadores de caminos. En definitiva,

\footnotetext{
${ }^{4}$ José Marcos Gutiérrez, Práctica criminal de España, Madrid, 1806, III, cap. VII, p. 149, incluía los supuestos de la Instrucción dentro de los delitos contra la administración de justicia, de modo que «los reos quedan sujetos por el hecho de tal resistencia a la jurisdicción militar, y ha de juzgarlos un consejo de guerra de oficiales».

${ }^{5}$ En este cuerpo legal figura la fecha de 30 de marzo de 1801, pero en Santos Sánchez, Colección de pragmáticas, cédulas, provisiones... expedidas por el Consejo Real en el Reynado del Señor don Carlos $I V$, Madrid, 1805, III , p. 151; o en Colón, Juzgados, III, p. 178, el año es 1802.
} 
eran procesados ante el consejo de guerra si la aprehensión de tales salteadores se hubiera realizado por tropas destinadas expresamente por las autoridades militares a su persecución y arresto, por un lado; o, por otro, si los malhechores hicieran resistencia con armas de fuego o blancas, aunque la decisión para su aprehensión la hubiera dictado la justicia ordinaria y la partida militar interviniera de orden, requerimiento o auxilio de autoridades civiles. En ambos casos, era indiferente que la detención se hubiera realizado en despoblado o en poblado. Todos los demás supuestos pertenecían a la jurisdicción ordinaria y en caso de tratarse de contrabandistas, sin delitos añadidos, a la de rentas.

La realidad, sin embargo, planteó nuevos litigios jurisdiccionales. La R.O. de 25 de marzo, inserta en la circular del Consejo de 16 de mayo de 1806, fue dictada a raíz de la competencia surgida entre el gobernador de la Sala del Crimen de la Real Audiencia de Sevilla y el juzgado militar, motivada por la entrega de los reos aprehendidos por la justicia ordinaria como cómplices de Marcos Pérez, capitán de una gavilla, preso y procesado por la jurisdicción militar. Se estableció que en ese y otros asuntos semejantes «conozca de todos la jurisdicción en donde se hallare el reo principal; y no constando cuál es, o dudándose de él, la que primero hubiere comenzado a conocer» ${ }^{6}$. Por tanto, no se decantaba, en principio, por la preeminencia de ninguna de las dos jurisdicciones.

\section{Las medidas legislativas tras la guerra}

La finalización de la guerra contra el ejército napoleónico y la vuelta del absolutismo en el verano de 1814 propiciaron el fresurgimiento o la aparición de grupos armados dedicados a la delincuencia en las zonas rurales y, como se ha señalado, particularmente en los caminos. Se produce, además, un fenómeno nuevo. Es una etapa que viene marcada por la distinción entre delitos regulados por la obsoleta legislación medieval y moderna, más propicia al arbitrio judicial; y unos nuevos delitos políticos o de Estado, objeto de disposiciones en las que la presión regia poco margen otorgaba a las autoridades encargadas de juzgarlos, puesto que no sólo conocerían de ellos los jueces y tribunales ordinarios sino también la jurisdicción militar.

La delincuencia organizada en gavillas no solo fue la de mayor actividad, sino que también resultó ser la más perseguida, no siempre con los resultados deseados por los organismos de la Corte. Estas gavillas, sobre todo tras la victoria contra el ejército francés, representaron no solo un conjunto de ladrones que atentaban por doquier contra el derecho de propiedad. Eran una fuerza armada que solo podía combatirse con las mismas armas en las manos, por tanto y como resulta obvio por el Ejército. Al intervenir los militares, dotados de jurisdicción propia, y, en principio, considerada con mayor celo represor, la lógica del absolutismo iba a depositar en ella la persecución y enjuiciamiento de estos grupos organizados de delincuentes.

\footnotetext{
${ }^{6}$ Suplemento de la Novísima Recopilación, 12, 17, 1, nota 2.
} 
Además de estos consejos se crearon comisiones militares para el procesamiento de quienes atentaran de obra o palabra contra la soberanía de Fernando VII. En consecuencia, mediante dos órganos judiciales diferentes, las autoridades militares actuaron para castigar las actuaciones políticas y los delitos contra la propiedad. En 1824 se perfeccionarán los sistemas represores, y la dualidad de órganos del Sexenio dejará paso a las comisiones militares que asumirán las atribuciones de los consejos de guerra y de las comisiones extraordinarias del período anterior ${ }^{7}$.

Estas comisiones tuvieron su origen en la ciudad de Cádiz en 1814. Se implantaron en toda España en virtud de la R.O. del Ministerio de la Guerra de 6 de septiembre, bajo la tutela de los capitanes generales ${ }^{8}$. Escapa de estas páginas su estudio, por centrarse en los consejos de guerra y la delincuencia patrimonial ${ }^{9}$. En virtud del R.D. de 26 de enero de 1816 se dispuso la supresión de las comisiones extraordinarias que entendían de ciertas causas criminales, señaladamente las políticas, encomendando el conocimiento de las mismas a la jurisdicción ordinaria. No obstante, en el mes anterior motu proprio el rey había condenado a medio centenar de constitucionalistas, ya que la Comisión de las causas de Estado no había funcionado como él pretendió. Otros encausados por motivaciones políticas no corrieron igual suerte, pues las comisiones militares actuaron excesivo con rigor punitivo.

A diferencia de lo que sucederá durante la Década ominosa, durante el Sexenio absolutista no se combinó, al menos por parte de las autoridades, la delincuencia patrimonial con referencias constitucionales o políticas. No encontramos referencias en la documentación oficial a que los ladrones y bandidos juzgados por los consejos de guerra habían

\footnotetext{
${ }^{7}$ A partir de la R.O. de 6 de septiembre de 1814, por la cual se ordenó que se procediese sumariamente y con arreglo a la Ordenanza del Ejército contra los que conspiraban contra el sosiego y la tranquilidad pública, Pedro Pegenaute Garde (Represión política en el reinado de Fernando VII: las comisiones militares (1824-1825), Pamplona, 1974, pp. 33-34) afirma que «no debe suponerse que estas Comisiones militares -se refiere a las de 1814- guardan una estricta relación con los tribunales especiales que con el mismo nombre fueron mandados establecer en enero de 1824; puesto que, tanto en el procedimiento como en la competencia (las Comisiones de 1814 fueron creadas para castigar exclusivamente los delitos políticos), las diferencias son evidentes». Es obvio que las Comisiones militares de 1824 vinieron a fundir en ellas las competencias de los consejos de guerra de 1814 y de las comisiones extraordinarias creadas para castigar a los constitucionalistas.

${ }^{8}$ Se determinó que «en el preciso término de tres días forme causa, la sustancie y concluya con arreglo a las leyes militares, que deben obrar en tales casos contra todas las personas que sean acusadas de hablar directa o indirectamente, en qualquier parage que sea, sobre asuntos que toque a la soberanía del Rey jurado solemne y repetidamente por la nación, y reconocido por todas las Potencias de Europa, u otras de su especie capaces de alarmar o causar sediciones, partidos o alborotos, o de distraer a qualquiera persona, o parte del pueblo de la pronta y justa obediencia a las disposiciones del Soberano, y de cumplir las de las autoridades que conspiran al buen orden y seguridad general». La comisión militar de Cádiz sentenció a tres individuos el 17 de septiembre de 1814 (Mercurio gaditano de 19.09.1814). La orden para el establecimiento de la comisión militar de Valencia en Diario de Valencia (en adelante $D d V$ ) de 16.09.1814. Manejo los ejemplares digitalizados de la Biblioteca de la Universidad de Valencia.

${ }^{9}$ Entre otras muchas obras, Ignacio Lasa Iraola, «El primer proceso de los liberales, 1814-1815», Hispania, 30, 1970, pp. 327-383.
} 
aludido, en algún momento de la perpetración de sus hechos, a la defensa de la Constitución de 1812 o habían dado voces a favor de alguno de los muchos conspiradores.

Por otra parte, Fernando VII poco va a innovar en materia legislativa criminal. Se va a limitar a reproducir, en la mayoría de los casos literalmente, las normas dictadas por su abuelo y su padre. El 22 de agosto de 1814 se expidió la Real cédula por la cual se mandan guardar y cumplir las instrucciones insertas para la persecución y castigo de los malhechores que infestaban los caminos del reino. Su contenido y finalidad no eran nuevos, pues tomaba su fundamento en disposiciones del reinado de Carlos III ${ }^{10}$. Si a finales del siglo XVIII la formación de numerosas gavillas de ladrones había planteado ya un serio problema de criminalidad, éste se agravó tras la finalización de la guerra contra el ejército napoleónico, pues andaban vagantes, pero organizados, individuos armados que antes de la guerra ya eran malhechores, o habían formado parte en la guerrilla o habían pertenecido al ejército, bien fueran desertores o licenciados sin medios de subsistencia, que encontraron en los robos su medio de vida. Las disposiciones para su disolución no surtieron, en todos los casos, el fin pretendido. De ahí que, apenas transcurridos unos meses del retorno de Fernando VII, se adoptaran medidas para su represión ${ }^{11}$. Esta disposición modificaba la Real Orden de 1802 tanto por lo referido al consejo militar que habría de juzgar a estos reos, como en lo referido a la consulta de las sentencias al rey. Eran medidas orientadas a actuar con premura y facilitar el pronto castigo de los aprehendidos

\footnotetext{
${ }^{10}$ No es admisible señalar como antecedentes la Pragmática de 1734 contra los hurtos en la Corte, ni su extensión posterior a otros lugares, como sostuvo Pegenaute, Represión, p. 31, porque su conocimiento correspondía a la jurisdicción ordinaria, al menos hasta 1784.

${ }^{11}$ «Deseando el Rey mi augusto abuelo poner el más pronto y eficaz remedio a los desórdenes que se experimentaban con motivo de la multitud de cuadrillas de ladrones, contrabandistas y malhechores que se habían formado, tuvo a bien mandar expedir en 29 de Junio de 1784 la Instrucción que se estimó oportuna para el exterminio de tales delincuentes. Con el propio fin acordó el mi Consejo diferentes providencias; y habiéndose aumentando en estos últimos tiempos el número de los malhechores por las causas bien notorias de la deserción de los egércitos, libertad que tumultuariamente se había dado a los reos, disolución de algunas guerrillas, que autorizándose con el dictado de defensores de la patria se presentaban en los pueblos consternados ya de sus vejaciones e insultos, y proseguían en ellos fiados en la impunidad que les prestaban las nuevas instituciones, e imposibilidad de las autoridades para castigarlos y contenerlos, tomó el mi Consejo en consideración la necesidad de poner a estos males un remedio no menos conveniente que vigoroso y enérgico, cual lo exigía la seguridad de los caminos, el decoro de la nación y el respeto mismo de la justicia. Con este fin mando pasar a mis físcales los antecedentes del asunto, y con presencia de ellos propusieron las providencias que estimaron oportunas para el logro de tan interesante objeto: todo lo que me hizo presente el mi Consejo en consulta de 15 de julio próximo; y conformándome con su dictamen en lo principal, he tenido a bien mandar que para la persecución y castigo de los malhechores que infestan les caminos del reino, y hasta que se disipen sus cuadrillas, se guarde la instrucción que he remitido al mi Consejo; y en lo que no estuviese dispuesto en ella, la de 29 de junio de $1784 \ldots$ y que en la administración de justicia en lo criminal se guarden en todos los juzgados y tribunales las leyes existentes en marzo de 1808, derogando, como derogo, cuanto se haya decretado por las cortes que no sea conforme a ellas, como también me propuso el mi Consejo en la citada consulta». A esta real cédula acompañaba una instrucción de igual fecha.
} 
La mejor forma, y sin duda la única, de combatir a estas cuadrillas armadas era recurrir al ejército. Como en 1784, esta represión se centró en ambas Castillas, Extremadura, Aragón, Andalucía, Valencia y Cataluña por ser «adonde hay mayor necesidad de remedio», extendendiéndose con posterioridad a toda la Península y Baleares. El servicio de la tropa voluntaria destinada a su persecución «será tenido y reputado como de guerra en todas sus consecuencias». Correspondía al capitán general, «una de cuyas principales obligaciones es mantener el distrito de su mando libre de malhechores», determinar el número de tropas necesarias para ello, debiendo las justicias de los pueblos proporcionarles la ayuda requerida y noticias para el arresto de dichos malhechores.

A efectos del enjuiciamiento de los malhechores detenidos, el art. 5 de dicha Real cédula establecía que «en cada provincia se destinarán al pueblo que se señale, un número determinado de oficiales, desde brigadier hasta capitán inclusive, para que allí formen un consejo de guerra permanente, al cual asistirá un asesor letrado; de cuyo nombramiento y elección se dará aviso por la Secretaría de Estado y del despacho de la Guerra». Por tanto, la guerra contra estas gavillas y malhechores se llevaba a todas sus consecuencias: ser juzgados por un tribunal militar, aunque asistido por un letrado civil.

La persecución encomendada a militares, y para su enjuiciamiento un tribunal de igual naturaleza. Pero, ¿quiénes podían ser enjuiciados por este consejo de guerra permanente? El art. 7 de la Instrucción fernandina de agosto de 1814 lo determina: «Quedarán sujetos a este consejo de guerra todos los malhechores que fueren aprehendidos en camino, campo o despoblado, aunque hayan cometido en poblado el delito, así los que hagan resistencia a la tropa como los que no la hicieren, aunque no se justifique que son reos de otro delito que el de contrabando, siendo aprehendidos fuera de poblado, y los que habiendo delinquido en camino o despoblado se refugiaren a pueblo, y fueren allí aprehendidos $\rangle^{12}$. A disposición de este consejo permanente se pondrían todos los reos aprehendidos, y los efectos y armas con que lo hubieran sido, para ser juzgados y sentenciados. Por tanto, la resistencia armada a la tropa perseguidora deja de ser un elemento clave, bastando tan solo la captura por la partida militar. De esta manera, la Instrucción de 1814 (art. 7) variaba el criterio fijado en la de 1784 (art. 9). En consecuencia, la disposición fernadina ampliaba la jurisdicción militar en detrimento de la ordinaria, a pesar de que ambas instrucciones acompañaran a la Real cédula de 1814 .

Puesto que se trataba de obviar trámites y castigar en breve plazo a los delincuentes apresados $^{13}$, se encomendaba al jefe de la partida militar que los hubiera detenido «la

\footnotetext{
${ }^{12} \mathrm{Al}$ contrario, según el art. 11: «contra los demás malhechores que no fueren de dichas clases ni cómplices, con los que pertenecen a ellas, se abstendrá de proceder el consejo permanente, quedando sujetos a la justicia a quien corresponda el conocimiento de sus causas y delitos», es decir y en principio, a la justicia ordinaria.

${ }^{13}$ La supresión habitual de los careos, salvo cuando fueran conducentes o hubiera discordancia de los testigos con referencia a los hechos, encuentra su origen en la Orden de 26 de julio de 1803, dictada por
} 
instrucción necesaria del hecho y razón de los testigos presenciales de él, para que pueda por ella formarse la sumaria sin pérdida de tiempo, y constar del delito y delincuente, y administrarse justicia, ahorrando en estos procesos la no necesaria fórmula de los careos, a no pedirlos el defensor del reo por ser convenientes para su defensa». Celeridad en los trámites que no solo permitía juzgar sumariamente a los bandoleros, sino que para conseguirla se prohibió la posibilidad de plantear cualquier tipo de competencias entre la jurisdicción ordinaria y la militar. Con ello se pretendían solventar los problemas de la disposición de 1784. El consejo debía proceder conforme a la legislación anterior a marzo de 1808 y, por tanto, se entiende que con sujeción a las Reales Ordenanzas militares y asimismo a la Instrucción del 29 de junio de 1784 que se incorporaba, con matices, a la del 22 de agosto de $1814^{14}$.

Resuelta la causa, la sentencia debía sujetarse, igualmente, a la legislación militar, aunque se buscó una aparente garantía al obligar a consultarla a la superioridad. De esta manera el art. 10 de la Real cédula de agosto de 1814 establecía los posibles trámites a seguir y fijaba dos soluciones diferentes según el delito:

«Pronunciada sentencia se remitirá con el proceso al Capitán general de la provincia, quien la pasará al auditor de Guerra para que la examine con toda preferencia; si de esta revista del proceso la sentencia resulta arreglada, el Capitán general dispondrá se egecute sin dilación; mas si el auditor hallase motivo fundado que ofrezca duda, o exija consultarme el Capitán general, como presidente de la Audiencia territorial, nombrará tres ministros de ella, con cuyo dictamen decidirá o me consultará, extendiendo con claridad los fundamentos de la duda y consulta para mi Real determinación. En Castilla la Nueva el Capitán general pasará oficio al presidente de mi Consejo Real, para que nombrados tres ministros de la Sala de alcaldes de mi Casa y Corte decida con el dictamen de todos los procesos de dicha clase que ofrezcan duda ${ }^{15}$, o me consulte en caso necesario, según queda prevenido...

Todavía en los casos de resistencia con armas a la tropa, calificada esta, el consejo de guerra llevará a efecto su sentencia sin que sea necesaria la consulta, bastando la aprobación del comandante en gefe de la tropa destinada para este servicio en la provincia. Y lo mismo se observará siempre que fuere militar el reo, o este fuere aprehendido in fraganti constando de esta calidad».

«las dificultades que se tocan, para verificar los careos entre los reos presos en Écija, y los testigos que han declarado en la causa formada contra varios malhechores».

${ }^{14}$ Art. 9: «En las sentencias de los procesos que ocurrieren, arresto de los reos y calificación de las pruebas y administración de justicia, se observarán las leyes existentes en el año de 1808 al tiempo de la invasión francesa».

${ }^{15}$ Así, por ejemplo, en 1815: «No conformándose el Capitán general de esta provincia con la sentencia de pena de muerte impuesta a Roque García por el consejo de guerra permanente, me ha pasado el oficio oportuno a fin de que con arreglo a lo prevenido en el art. 10 de la Instrucción inserta en la Real Cédula de 22 de agosto del año último, nombre yo tres ministros de la Sala de alcaldes de Casa y Corte para que se decida con su dictamen el proceso formado a dicho reo; y deseando conciliar este servicio con los demás a que necesita atender la Sala espero que V.S. me propondrá los tres alcaldes que considere en más proporción al fin expresado con la posible brevedad». Fueron propuestos por el gobernador de la Sala Francisco Alfonso de Fuero, Joaquín Sisternes y Ramón Satué. AHN, Consejos, libro 1405, exp. 104. 
Es clara la diferenciación entre los reos que, al tiempo de la aprehensión, hicieran resistencia armada o fueran militares, del resto de los aprehendidos. Los primeros quedaban privados de la garantía que constituía la consulta a la autoridad militar superior.

\section{La actuación de los consejos de guerra permanentes de Castilla la Nueva y de Valencia y Murcia}

El consejo de guerra permanente de Castilla la Nueva se estableció unos días después de esta real cédula de agosto de $1814^{16}$. Quedó formado por un presidente ${ }^{17}$, ocho vocales con el grado de capitán pertenecientes a los diferentes cuerpos militares de la Corte, cuatro fiscales ${ }^{18}$, dos ayudantes y un capellán, además del secretario ${ }^{19}$. El asesor del tribunal será un abogado madrileño ${ }^{20}$. No tuvo sede fija, de manera que las

${ }^{16}$ «Siendo por desgracia tan crecido el número de malhechores que infestan los caminos y obstruyen el comercio, por lo qual ha sido indispensable adoptar medidas para cortar de raíz estos males; y siendo también un interés general, por el bien que resulta al Estado, el exterminar este género de hombres que corrompen las buenas costumbres y con su mal exemplo seducen y conducen a su ruina a los jóvenes incautos; ha sido, pues, preciso mirar este interesante punto con la gravedad que exige, y en su vista he nombrado un consejo de guerra ordinario, que se denominará de Castilla la Nueva, conforme a la Real Orden de 30 de abril de 1802, que S. M. ha tenido a bien poner en su fuerza y vigor, como también la de 1784, que trata sobre lo mismo; y en su cumplimiento, he nombrado por presidente de este consejo al brigadier de los Reales Exércitos D. Manuel de Villalva, teniente de Rey de esta plaza, por vocales a ocho capitanes de los cuerpos de esta guarnición, que con quatro fiscales, dos ayudantes y un capellán formen este Tribunal permanente. Igualmente he nombrado con el carácter de asesor a D. Lorenzo Hernán López, del ilustre Colegio de abogados de esta Corte, cuyos nombramientos han merecido la Real aprobación. Para que este consejo llene todos sus objetos, conforme a las Reales intenciones de S. M., encargo muy particularmente a las justicias de los pueblos sujetas a mi jurisdicción les faciliten a su presidente o fiscales los informes, noticias y demás documentos que les pidan, en el concepto de quede no hacerlo así, les haré el más severo cargo, y serán responsables a las resultas. Madrid 16 de agosto de 1814. José Arteaga» (El Procurador del Rey y de la Nación de 26.08.1814; y en Diario de Madrid (en adelante $D d M$ ) de 17.08.1814). Utilizo los números de la Hemeroteca digital de la Biblioteca Nacional de España.

${ }^{17}$ El brigadier Manuel de Villalba solicitó el relevo de la presidencia «por privarle del desempeño de las funciones de teniente de Rey». Fue sustituido por Ignacio Belanzar «con quien podrán entenderse los sugetos que tengan asuntos pendientes en dicho tribunal», DdM de 15.09.1815.

${ }^{18}$ El nombramiento de fiscal del consejo de guerra permanente a favor del capitán Francisco Villarejo, en AHN, Diversos-Colecciones, 73, n. 98. Desde julio de 1815 actuaron Manuel Monzonillo; Lucas López; Antonio de Tomás (teniente de Infantería); Francisco Paula Yarto (graduado de Infantería); José de Piedra (teniente coronel de Infantería); Antonio de Urquiza (capitán graduado de Infantería); José Toledo (capitán agregado al Estado mayor); Ildefonso del Pozo (teniente); Francisco Javier Caballos (teniente graduado de capitán).

${ }^{19}$ Intervinieron como secretarios el alférez Tomás Espinosa, el teniente coronel Fermín de March ODoyle desde julio de 1815 y Miguel Giro a partir de septiembre de 1815.

${ }^{20}$ «El asesor que debe asistir a estos consejos permanentes, ocupará el último lugar, no tendrá voto, y solo aclarará las dudas que ocurran al presidente y vocales, para asegurar mejor el acierto en el conocimiento de las pruebas y sentencia, debiendo expresarse su asistencia en la diligencia de haberse juntado el consejo, y pasado a la votación», Colón, Juzgados, III, p. 181. 
vistas se celebraron en la casa de sus respectivos presidentes ${ }^{21}$. Su actividad se concentró, sobre todo, en el bienio 1815-1816, en el que al menos se celebraron entre 30 y 40 consejos cada año. Desde noviembre de 1817 se reduce su actividad al enjuiciamiento de soldados que hubieran cometido delitos.

En el Diario de Madrid se publicaron hasta 1817 los edictos llamando a alguno de los encausados ${ }^{22}$, los anuncios de la celebración del juicios y algunas sentencias. A través de ellos podemos descubrir la importante función que desempeñaron los fiscales del consejo de guerra, a los que por su condición de instructores se les denominó en ocasiones juez-fiscal. El primer juicio de este consejo de guerra de Castilla la Nueva tuvo lugar el 17 de diciembre de 1814 contra los acusados de "varios delitos», advirtiendo que «los señores oficiales y cadetes de la guarnición que no estén de servicio asistirán al consejo; así como podrán hacerlo todas las personas que gusten ${ }^{23}$. Por su parte, el consejo de guerra de Valencia dictó su primera condena de muerte el 2 de octubre de $1814^{24}$.

Los consejos de guerra también anunciaban el día, el nombre, los hechos delictivos, la casa en que se celebraban y la misa de Espíritu Santo previa a su celebración ${ }^{25}$,

${ }^{21}$ Calle del Barco, n. 13 (DdM de 16.12.1814), de la Reina, n. 24 (DdM de 10.05.1815), plazuela del Ángel, n. 16 ( $D d M$ de 11.09.1815), de la Reina, n. 3 (16.11.1815).

${ }^{22}$ Como muestra: «Don Manuel Monzonillo, alférez graduado de teniente de regimiento de Dragones del Rey, y fiscal del consejo permanente de guerra de esta provincia. Hallándose ausente de esta Corte Pasqual Martínez, vecino de Carrascosa, contra quien se ha seguido causa criminal del real oficio de la justicia en la villa de Valparaiso de Abaxo con otros sus consortes, presos en estas reales cárceles, sobre diferentes robos executados en Langa y otros sitios de los montes de Albuceyte en el año de 1812, continuándose dicha causa por este tribunal, y actuando en ella al presente; usando de la jurisdicción que el Rey nuestro Señor tiene concedida en estos casos por sus Reales Ordenanzas a los oficiales de su Exército, llamo, cito y emplazo por este primer edicto a dicho Pasqual Martínez, señalándole la casa donde actualmente reside el expresado consejo en la calle de la Reyna, núm. 24, quarto principal, donde deberá presentarse personalmente dentro del término de diez días, que se cuentan desde el de la fecha, a dar sus descargos y defensas; y de no comparecer en el referido plazo, se seguirá la causa y sentenciará en rebeldía por el consejo de guerra enunciado con lo demás a que hubiese lugar, sin más llamarle ni emplazarle, por ser esta la voluntad de S.M. Fíxese este edicto para que llegue a noticia de todos. Madrid 11 de agosto de $1815 »$ ( $D d M$ de 12,16 y 19.08.1815).

${ }^{23} D d M$ de 16.12.1814. Esta apostilla se insertó en los primeros anuncios, pero no tardó en omitirse, pues desapareció desde comienzos de marzo de 1815. De igual manera en Valencia: «Consejo de guerra ordinario. Hoy lunes 16 del corriente se celebra consejo de guerra al paisano Francisco Aznar (alias el Tuno de Algemesí) acusado de robos rateros, en la sala de dicho consejo, calle de las Barcas, casa de la señora condesa de la Concepción, a las nueve horas de la mañana. Se permitirá la entrada a todo sugeto con trage decente que quiera asistir a este acto», $D d V$ de 16.01.1815.

${ }^{24} D d V$ de 3.10.1814, Continuación. En el número del día 20 de octubre se da cuenta de haber destinado a otro reo por robos durante seis años a presidio.

${ }^{25}$ Por ejemplo: «El viernes 7 del corriente serán juzgados por este tribunal Ventura Olaya, Cesáreo Dones y Demetrio Pedraza, vecinos de La Guardia, acusados de robos. A las 8 se dirá la misa de Espíritu Santo en la iglesia del colegio de Niñas de Leganés, y concluida pasará a celebrarse el consejo en la casa de su presidente calle de la Reyna, número 24, quarto principal. Madrid 5 de julio de 1815. Fermín de March O-Doyle, teniente coronel, secretario», $D d M$ de 6.07.1815. «Hoy celebra la plaza consejo de 
aunque solo en los casos más graves contamos con información del resultado del proceso. El juicio se desenvolvía en casa del presidente, a la cual era conducido el reo desde la cárcel y a la que volvía tras su celebración. Entre la celebración de la vista y la ejecución de la sentencia apenas mediaban unos días, pues necesitaba obtener el placet del capitán genera ${ }^{26}$. Los bienes recuperados sobre los que no constaba su dueño eran subastados ${ }^{27}$.

Por su parte, el Diario de Valencia publicó las condenas capitales, los reos que habían de sufrirla, el hecho por el que había sido juzgados y el lugar de ejecución ${ }^{28}$. No es habitual encontrar en sus páginas anuncios sobre la celebración del juicio, aunque alguna noticia podemos hallar.

El consejo de guerra de Castilla la Nueva buscó la colaboración de las justicias ordinarias, tanto para el arresto de acusados ${ }^{29}$, como también para conocer los posibles antecedentes criminales de los encausados ${ }^{30}$, aunque como consecuencia de la guerra

guerra por la comisión militar de esta plaza en la sala de Audiencia de la Real cárcel a las diez de la mañana para juzgar a José Vázquez Ordoñes (a) Calandares, acusado de robos en despoblado. La misa de Espíritu Santo se dirá en la iglesia de Santo Domingo a las nueve de la mañana», Diario Mercantil de Cádiz de 16.02.1819.

${ }^{26}$ La vista contra Francisco Auñón tuvo lugar el 1 de febrero y fue ejecutado el día 10, DdM de 31.01 y 10.02. 1815. Era soldado del Regimiento de Húsares Españoles, de 33 años, casado y procesado por hurto con homicidio que confesó. Morales, Historia del Saladero, II, p. 245.

${ }^{27}$ «Debiendo efectuarse la venta de varias ropas y efectos, correspondientes a diferentes causas seguidas en este tribunal, se avisa al público para que las personas que quieran tratar de ajuste se presente desde el viernes 19 y siguientes en la secretaría del consejo, calle de la Reyna, número 24, quarto principal, de 9 a 11 por la mañana» ( $D d M$ de 16.05.1815). También en $D d M$ de 16.10.1815 y 4.02.1816.

${ }^{28}$ «Consejo de guerra permanente. Sentencia. Mañana, a las 11 de ella, será pasado por las armas en las inmediaciones de la real aduana Francisco Lloret, por el delito de robo en despoblado, y heridas causadas con alevosía y ventaja a Vicente Ripoll, según sentencia de este tribunal, aprobada por el excelentísimo señor capitán general. Valencia 20 de enero de 1815. José A. de la Rosa, secretario», $D d V$ de 20.01.1815. ${ }^{29}$ «Inmediatamente que recibí el oficio del señor presidente del consejo permanente de guerra, fecha de aier y que V.S. me remitió para que se procediese a la prisión de Fulgencio Montalbo, y su muger, vecinos de la villa de Ontanaya, reos procesados por dicho tribunal y que se les pusiese en la cárcel de Corte sin comunicación a disposición del mismo Consejo, mandé a los ministros de mi ronda practicasen las más activas diligencias para verificar dichas prisiones, y en la noche de aier a las 8 y media se prendió a Juliana Molero... Por las indagaciones echas a seguida resulta que dicho Montalbo es jornalero, y que ha salido de Madrid a buscar trabajo en el día de aier sin saber a qué pueblo...», fechada el 30 de diciembre de 1815 (AHN, Consejos, libro 1405, exp. 183). Por oficio del presidente del consejo de guerra permanente, acompañando el del fiscal de la causa contra Raymundo González y Pedro Guijarro, solicitaba el arresto de Manuel Maeso, «o sea Melitón Mayo, que vive calle del Águila, por el cual manifestaba que al haberse enterado que Mayo estaba avecindado en Madrid». El alcalde de barrio «habiendo hecho la investigación correspondiente encontró un tal Manuel Maeso con quien idénticamente conbienen las señas de Melitón Mayo por su edad, por su exercicio, por su familia, y por el tiempo en que se presentó en esta Corte» (AHN, Consejos, libro 1405, exp. 1).

${ }^{30}$ «Hallándome entendiendo como fiscal del consejo de guerra permanente de esta provincia, en causa contra Gregorio Hernando preso en las Reales cárceles de Villa de esta Corte, sobre haber expendido licencias y pasaportes falsos; y resultando de su misma declaración haber estado preso en las cárceles expresadas, he de merecer de V.S. se sirva mandar que el alcaide de dichas cárceles certifique con arreglo 
no siempre fuera fácil su obtención ${ }^{31}$. Estos antecedentes servían a los jueces militares para agravar las penas al considerarlos reincidentes. En otras ocasiones se alentaba la colaboración de las posibles víctimas ${ }^{32}$.

En la referencia de la sentencia siempre se indica que vista la causa contra reo que se identifica por su nombre y alias, que fue condenado a determinada pena y que la sentencia quedó aprobada por el Capitán general de Castilla la Nueva, al tiempo que disponía el destino concreto del reo $^{33}$. En ocasiones se insertan apostillas. Como por ejemplo la relacionadas con la pena de azotes: «queriendo S.M. señalar con un rasgo de su real clemencia su glorioso enlace con la Reyna nuestra Señora, ha tenido a bien indultarle de la pena de azotes, mandando cumpla la de presidio» ${ }^{34}$.

La actuación de los consejos de guerra permanente iba más allá del fallo. En las referencias de las sentencias ejecutadas publicadas en el Diario de Madrid, es habitual leer alguna admonición del consejo de guerra de Castilla la Nueva. Todas tienen la idéntica finalidad y actúan como pregón impreso de la decisión del tribunal militar, siendo habitual encontrarlas en las que anuncían el ajusticiamiento de algún reo. Así por ejemplo, se señala: «Tiemblen los malvados con el fin que les aguarda, si no enmiendan su depravada vida, haciéndose útiles al Estado» ${ }^{35} ;$ «... y se hace saber para escarmiento de los perversos, que deben convencerse de la suerte que les espera si no abandonan su mala vida, ocupándose en honroso trabajo, en beneficio del Estado y propia utilidad $»^{36}$; «... y se ha executado en el día de hoi en esta plaza para escar-

a lo que resulte de los libros de entrada y salida de presos la causa de la prision de Hernando y su éxito, en el concepto de que la prisión de Hernando se verificó en el año pasado de 813 y día 14 de diciembre». 10 de agosto de 1815 .

${ }^{31}$ AHN, Consejos, libro 1405, exp. 37. «Resultando por la causa que sigo contra Bruno Crespo, natural de Noblejas, haver sido sentenciado a presidio por ese Tribunal, se servirá V.S. decirme en qué tiempo fue dicha sentencia y los motivos que la originaron, con quanto V.S. sepa sobre el particular y combeniente para la sustanciación de la causa». 6 de febrero de 1816. Por la certificación, resultaba que no había datos de su condena ni había sido comprendido en ninguna de las cadenas que han salido de la Real Cárcel de la Corte. AHN, Consejos, libro 1407, exp. 120.

${ }^{32}$ Así por ejemplo: «Hallándose entendiendo en la averiguación de los robos executados en los sitios llamados, la casa de la Angorrilla y Tres Cantos, pertenecientes al real bosque del Pardo, D. Pedro Antonio Díaz, escribano de S.M., del número y ayuntamiento de la villa de Aravaca, y de diligencias del consejo de guerra permanente de Castilla la Nueva, en virtud de comisión particular del Excmo. Sr. Capitán general de la misma, y gobernador político y militar de Madrid y su provincia; se hace saber a todas las personas que fueron robadas en aquellos sitios, unos en 3 de agosto, y otros a fines de noviembre del año próximo pasado de 1814, comparezcan ante dicho escribano a dar razón de los efectos y dinero que les robaron, para en su vista proceder con el rigor de la ley contra los executores de estos crímenes, debiéndose presentar los que se sientan agraviados en la casa del señor presidente del mencionado consejo, calle del Barco, núm. 13, en el preciso y perentorio término de 15 días, contados desde el 15 del corriente mes de marzo» (DdM de 16.03.1815).

${ }^{33}$ «... cuya sentencia aprobada por el Escmo. Sr. Capitán general en 3 de agosto, le señaló a Rey el presidio de Melilla», $D d M$ de 14.08.1817.

${ }^{34} D d M$ de 9.10 .1816$.

${ }^{35} \mathrm{DdM}$ de 18.07.1816.

${ }^{36} \mathrm{DdM}$ de 3.12.1815. 
miento de los malvados» ${ }^{37}$; o, «Los criminales que no arreglen sus depravadas costumbres vean la suerte que les aguarda, y por el contrario las beneficencias del Soberano que en lugar del castigo desea el arrepentimiento ${ }^{38}$. Tras el ajusticiamiento de Antonio Sánchez, el famoso Chorra al aire, se envió a la Sala de alcaldes de Corte un impreso con el fin de que se fijara en el patio de la Real cárcel de Corte «a fin de que sirva contener a los demás presos en la debida moderación ${ }^{39}$. Una de las advertencias más peculiares se incluye tras el anuncio de la ejecución de Lima y Derecha en abril de 1816:

«... ha sido executada en este día para escarmiento de los malvados, y que se convenzan de la suerte que les espera si no tratan de abandonar su criminal ocupación.

Al paso que este tribunal castiga con el rigor de la ley a los delincuentes para que sirva de freno a otros, sabe distinguir a los verdaderos inocentes, y a aquellos que más bien por un efecto de la debilidad humana, que por depravación de costumbres incurren en delitos leves, así es, que de esta clase ha puesto en libertad, y dirigido a los pueblos de su naturaleza, para que puedan ser útiles al Estado, dedicándose el honroso trabajo a...» ${ }^{40}$.

Por su parte, el consejo de guerra de Valencia y Murcia en el anuncio de la sentencia por la que fueron condenados dos desertores y dos paisanos por robos y otros excesos, insertó esta texto:

«Y para que este acto de Justicia, tenga en sí todo el aparato imponedor que exige la vindicta pública y la multitud de bandidos que infestan las provincias, atacando impunemente con tanto descaro y olvidos de sus deberes sociales, la propiedad y seguridad individual del ciudadano indefenso, quiere S.E. consiguiente a la misma sentencia del consejo, que luego que los indicados reos sufran la pena de muerte, sean mutiladas las cabezas de los dos primeros (se refiere a los desertores) por manos del verdugo, y colocadas en los parages más públicos de esta ciudad y la de Orihuela, a fin de que amendrentados los compañeros que todavía inundan los caminos y despoblados, entren en sí mismos, y persuadidos de la irresistible fuerza y vigilancia de la ley, se abstengan ya de continuar en sus desórdenes» ${ }^{41}$.

Como complemento de las estas medidas castrenses y represivas, en aras de una mayor eficacia que a la postre resultó frustrada, se dictó el Reglamento de las coman-

${ }^{37} D d M$ de 11.01 .1816$.

${ }^{38} \mathrm{DdM}$ de 23.11.1817.

${ }^{39}$ AHN, Consejos, libro 1406, exp. 113.

${ }^{40} D d M$ de 23.04.1816. Por parte de la autoridad militar se ofició al teniente de corregidor dando aviso de haberse entregado a los reos condenados a muerte y a sus compañeros. Lima y Escribano quedaron en capilla para que se verificara la sentencia el lunes 22 de abril de 1816, después de las doce. Ese día: «Ahora que es la una y media de la tarde de este día, acavan de sufrir la pena capital de garrote los reos Alfonso Domínguez (alias Lima) y Josef Escrivano, y la de presencia de la ejecución de esta sentencia, y pena de doscientos azotes, los reos Vicente Villaseca, Dionisio Muñoz y Josef Castillo, y la de vergüenza Luis Sánchez Guzmán, sin otra novedad que la de haverse aplastado la cuvierta de dos cajones de madera, por el mucho gentío que se ha suvido a ellos, mas no ha ocurrido desgracia alguna». AHN, Consejos, libro 1406, exp. 157, y libro 1407, exp. 70.

${ }^{41} D d V$ de 29.10.1814. Los cuatro fueron pasados por las armas. 
dancias militares de 10 de agosto de 1815. En su proemio se exponía la situación de criminalidad existente, achacándola a «las anteriores desgraciadas circunstancias que ha sufrido la nación durante mi cautividad, ya sea en la guerra destructora que ha tenido que sostener, ya por las innovaciones que ha tolerado a consecuencia de ella el sistema general de las cosas». La consecuencia de ello fue el aumento de la delincuencia, la comisión de delitos, el perjuicio del comercio y la amenaza a los patrimonios. La solución adoptada fue la creación de estas comandancias ${ }^{42}$. Poco después fueron suprimidas ${ }^{43}$.

A los comandantes se les señalaba como primera obligación, esmerarse «en la persecución de los desertores, ladrones, contrabandistas y malhechores, en el sosiego de los pueblos, en la seguridad de los caminos, en el auxilio a las justicias, en la protección de los vecinos honrados; notarán las faltas de observancia en el cumplimiento de las leyes y disposiciones soberanas» (art. 7). En concordancia con tal deber, el art. 9 disponía que: «No omitirán medio ni modo alguno para enterarse de si en su propia provincia o distrito existe gente de mal vivir, esto es, delincuentes públicos, como desertores, bandidos, contrabandistas y malhechores; y con arreglo a lo prevenido en el tít. 12 , trat. $6^{\circ}$ de la Ordenanza respecto a los desertores, y a las instrucciones que sobre este punto se les dieren, procederán desde luego a activar su aprensión, oficiando a las justicias de su jurisdicción para que les faciliten las noticias que pidieren; lo que deberán cumplir sin pretexto ni dilación alguna, bajo la pena en su caso que se les impondrá más adelante; lo que asimismo verificarán relativamente a los lemas

${ }^{42}$ «... prevalidos algunos hombres con poca religión y sin temor a la justicia han aumentado y aumentan el dolor y angustia de sus conciudadanos, cometiendo los crímenes horrorosos del latrocinio, asesinato, y otros que comprometen la pacífica y dichosa quietud de sus hermanos; y viendo que a pesar de las enérgicas medidas que he dictado no ha podido hasta ahora cortarse de raíz tal desorden, pues inundan los pueblos y campos malvados que afligen a los vecinos y viajantes con continuos robos, muertes y otros delitos de igual naturaleza, sin que el labrador pueda con sosiego atender a sus labores, el comerciante a sus tráficos, el traginero a sus conducciones, ni los demás individuos del Estado a los objetos de su interés sin zozobras ni sobresaltos, y con grave perjuicio por todo y en todas maneras de mi Real erario... cerciorado por experiencia de la necesidad de dictar medidas que los contengan, y castigando a los delincuentes eviten nueva y escandalosa perpetración de delitos públicos por los desertores, ladrones, contrabandistas y malhechores, conciliando al mismo tiempo los intereses más sagrados del Estado para que las leyes tengan el vigor que les conviene, los magistrados y justicias el respeto que les compete, mis disposiciones soberanas la obediencia y cumplimiento que se les debe, todos mis amados vasallos aquella paz y seguridad real e individual que les corresponde para atender a sus propiedades, trabajos y egercicios... he tenido a bien, conformándome en lo principal con lo que me ha consultado mi Supremo Consejo de la Guerra, y con lo que me espuso mi Secretario de Estado y del Despacho de la Guerra en 29 de junio último, crear en todas las provincias de la Monarquía comandantes militares, que a la par que se empleen en los objetos que he estimado oportuno confiar a la probada conducta y acreditado servicio de los dignos defensores de mis sagrados derechos y los de la patria, celen, vigilen y contengan los referidos desórdenes».

${ }^{43}$ R.D. de 24 de octubre de 1815, «mandando que para llenar su objeto relativo a la persecución de los malhechores y logro de la tranquilidad pública en todo el reino egerzan las autoridades respectivas las facultades que les dan las leyes en los mismos términos que se ha verificado hasta el año de 1808 sin innovación alguna». Gaceta de Madrid (en adelante Gaceta) de 31.10.1815. 
delincuentes públicos; observándose en cuanto no queda derogado por este reglamento lo que está mandado por mi Real cédula de 22 de agosto de 1814, que inserta la instrucción espedida por mi augusto abuelo en 29 de junio de 1784». Conocida la presencia de delincuentes o desertores deberían dictar las oportunas decisiones para su persecución y detención.

Una vez adoptadas las medidas represivas, «en cualquiera de estos casos se actuará una información militar sumaria del suceso, y en el momento de haberse verificado, poniendo a su cabeza la orden con que han procedido los comisionados, la delación firmada por el sugeto que la da (pues no admitirán alguna sin este preciso requisito, y sin que ofrezca comprobación del aviso u noticia), o el oficio de la justicia o autoridad que motiva la prisión; pues aunque el comandante de estas pueda recibirlo en voz conforme al art. 4 de la Instrucción de 22 de agosto referida, y deberá disponer lo conveniente para su auxilio con mano fuerte al momento, exigirá después de la que fuere oficio motivado u testimonio en que conste la causa u origen del procedimiento, que de ningún modo podrán negar» (art. 13). Tras la prisión de los delincuentes, los trámites se sujetarían a la Instrucción de 1814, «ya sean desertores o vagos, ya malhechores o contrabandistas». Practicada la sumaria, se comunicaría a las autoridades superiores para que dispusieran lo conveniente: remisión de los desertores a sus cuerpos; destinos según la Ordenanza de vagos; o «entrega a disposición del consejo permanente de la provincia de los últimos; en el concepto de que todos los presos que la jurisdicción militar haga por delitos públicos deben ser juzgados por estos tribunales conforme al art. 7 de la Instrucción de 22 de agosto» (art. 15).

El funcionamiento de los consejos de guerra permanentes no debía de satisfacer a las autoridades de la Corte. En su consecuencia, el 19 de septiembre de 1815 se envió a las capitanías generales una Real orden del Ministerio de la Guerra para su activación, especialmente en los procesos contra desertores, alertando del «crecido número de causas que se hallan pendientes en los consejos de guerra permanentes de las provincias». Se solicitó al Consejo supremo de Guerra que propusiera lo conveniente para su pronta terminación, aunque mientras no lo hiciera los capitanes generales deberían aplicar «todo su zelo para activarlas desde luego, y que con respecto a los desertores de segunda vez que no estén complicados en otros delitos, ni estén comprendidos en el soberano indulto de 30 de mayo último, se observe la Real orden de 7 de enero de 1799». De conformidad con esta última y debido al «crecido número de desertores de segunda vez que permanecen en los calabozos de los respectivos cuerpos», se determinó que inmediatamente que se arrestara a un desertor por segunda vez, le recibiera declaración el ayudante, averiguando los motivos que tuvo para reincidir y si existiera alguna excepción importante para su defensa. No probándose ninguna excepción, se le destinaría sin dilación a presidio; pero «si el reo alegase alguna excepción de gravedad, sea procesado y juzgado en consejo de guerra conforme a Ordenanza $\rangle^{44}$. Esta disposición aceleró, ciertamente los procesos resueltos por los

${ }^{44} \mathrm{DdV}$ de 31.10 .1815$. 
consejos de guerra permanentes, puesto que se advierte una gran diferencia numérica entre los resueltos en 1815 y los sentenciados en 1816.

En Valencia, su capitán general, Javier Elío, actuó con gran dureza en la represión del bandolerismo y, en general, con los robos en despoblados. Teniendo presente la deplorable situación económica de Valencia y las consecuencias sociales de la posguerra, existieron importantes cuadrillas de bandoleros por todo el reino valenciano. Contra ellos actuó, tanto en su persecución como en la confirmación de las penas de muerte impuestas por los consejos. En este sentido, contrasta el número de reos ajusticiados por mandato del consejo de Castilla la Nueva con el de Valencia y Murcia, a pesar de entrar en la jurisdicción de aquel la Corte y Sitios Reales, lugares de especial protección.

El general Javier Elío utilizó la difusión del Diario de Valencia para dar publicidad a las ejecuciones de delincuentes juzgados por el consejo de guerra permanente, para lo que dispuso la inserción mensual de las condenas de muerte dictadas por este tribunal. Así lo determinó en su circular de 6 de mayo de 1816: «Para que los castigos impuestos por la jurisdicción militar a los delincuentes que son sentenciados por ella, produzcan todo el objeto con que las leyes los determinan, para que en las provincias de mi mando no quede morador que no se halle con noticia del triste fin que han tenido los miserables cuyos crímenes los han conducido a la presencia de la justicia, y para que a todos alcance el aviso del término de espera a los que se separan del camino de la virtud con perjuicio de la sociedad, he determinado circular mensualmente una lista de las sentencias de muerte que se egecutan.... $\rangle^{45}$. En el estadillo debía hacerse constar la condición de soldado o paisano, el nombre, el pueblo de su naturaleza, los delitos que hubiera cometido, la modalidad de la ejecución -pasado por las armas, garrote u horca- y el paraje y día de la ejecución. No todos los condenados fueron ajusticiados en las ciudades sede de los consejos permanentes. Elío, incluso, buscó la ejemplaridad de los castigos no solo publicando la noticia de las ejecuciones, sino también ajusticiando a varios reos al mismo tiempo, con independencia de que los paisanos lo fueran en una plaza y los militares en otro paraje. Mientras en Madrid las ejecuciones colectivas son excepción, en Valencia encontramos ajusticiamientos de 5, 7 o 10 reos.

Los datos de los sentenciados por el consejo de guerra permanente de Valencia y los ordinarios establecidos en Murcia, Alicante y Orihuela durante todo el año 1816 dan buena cuenta de la represión ejercida por estos tribunales. A pesar de que no aportan datos sobre los hechos sentenciados, sí lo hacen sobre la información final de las condenas en la que destaca el $18 \%$ de condenas a muerte impuestas por estos cuatro tribunales militares ${ }^{46}$ :

${ }^{45} \mathrm{DdV}$ de 15.05 .1816$.

${ }^{46} D d V$ de 27.02.1817, reproducido en Diario Mercantil de Cádiz de 17.03.1817. Más información sobre algunos de los enjuiciados en los consejos de guerra valencianos en Manel Arcos i Martínez, La senda dels lladres. Bandolerisme als voltants de la serra de Mostalla (1806-1839), Valencia, 2009, pp. 73-80. 
Consejo de guerra permanente de Valencia y Murcia:

$\begin{array}{ll}\text { A pena capital pasados por las armas } & 16\end{array}$

A pena capital dados garrote $\quad 22$

Destinados a los presidio de África $\quad 11$

A otros presidios $\quad 16$

$\begin{array}{ll}\text { Segregados del Consejo pasados a la Justicia real ordinaria } & 12\end{array}$

$\begin{array}{ll}\text { Puestos en libertad en virtud de Reales indultos } & 14\end{array}$

Puestos en libertad indemnes en entera libertad $\quad 36$

A reclusión tres mujeres $\quad 3$

Libertad a una mujer 1

Total 165

Total de procesos en que estaban comprendidos $\quad 76$

Consejo de guerra del reino de Murcia:

A pena capital. Dados garrote 2

Destinados a varios presidios $\quad 3$

Idem al servicio de armas $\quad 2$

Segregados de la Comandancia y entregados a la Justicia real ordinaria 2

Puestos en libertad en virtud de Reales indultos $\quad 12$

Idem después de haber sufrido la sentencia impuesta 1

Idem indemnes en entera libertad $\quad 16$

Total 39

Idem de procesos en que estaban comprendidos 16

Consejo ordinario de la plaza de Alicante:

A pena capital pasados por las armas 1

$\begin{array}{ll}\text { A pena capital ahorcados } & 2\end{array}$

Azotes. Destinados a los presidio de África 1

Total 4

Idem de procesos en que estaban comprendidos 3

Consejo de Orihuela:

A pena capital, pasados por las armas $\quad 4$

$\begin{array}{lr}\text { Destinados a los presidios de África } & 10\end{array}$

Destinados a otros presidios 9

Destinados al servicio de las armas 2

Segregados del Consejo y pasados a la Justicia Real ordinaria 2

Puestos en libertad 9

Total $\quad 36$

Idem de causas en que estaban comprendidos $\quad 22$

Tras la publicación de este resumen, las páginas del Diario de Valencia no vuelven a insertar ninguno otro anual, aunque sí figuran resumenes trimestrales ${ }^{47}$.

Resulta llamativo establecer la comparación con las penas corporales dictadas por la Sala del Crimen de la Real Audiencia de Valencia, puesto que permite cotejar cómo actúan los tribunales de ambas jurisdicciones. En 1816 los alcaldes del crimen condenaron a muerte a 7 individuos; 409 fueron destinados a presidio; 210 encerrados

${ }^{47} \mathrm{DdV}$ de 9.07.1817. 
en la cárcel y hospicios; 45 desterrados; 166 destinados a las armas o trabajos públicos; y se vieron 45 causas de indulto.

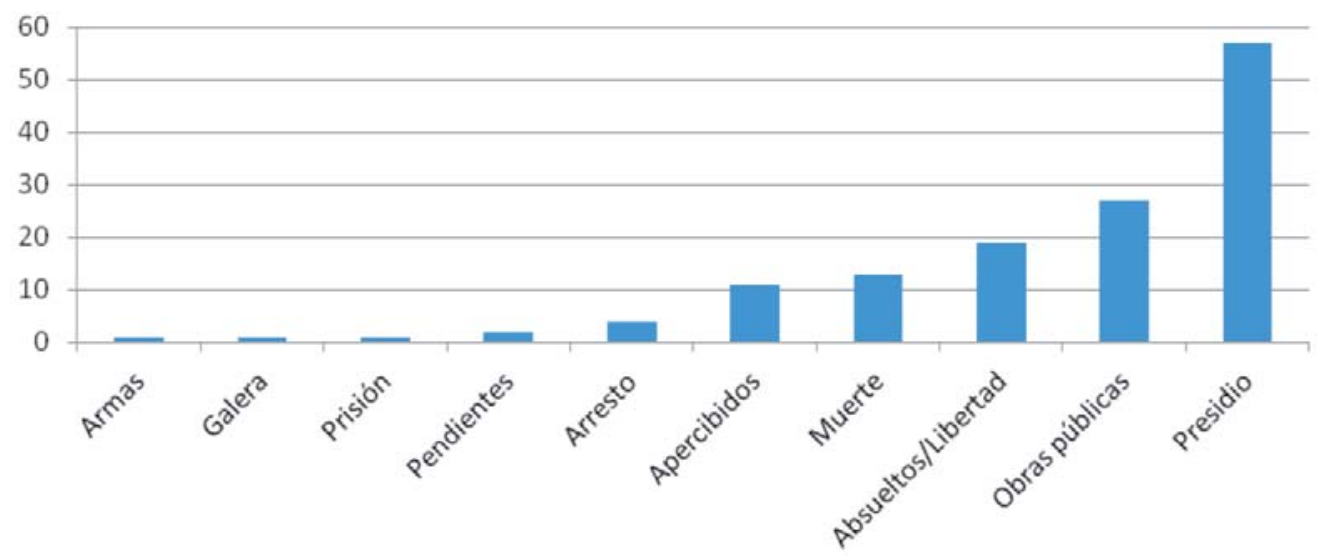

El arco punitivo en el que se movió el consejo de guerra de Castilla la Nueva es muy reducido. Sus condenas tienen un marcado destino militar, siendo el envío a presidio la más habitual, no encontrándose otras penas corporales ni la imposición de pecuniarias, que excepcionalmente impuso el consejo permanente valenciano.

Entre los rematados a presidio predominan los enviados a Ceuta, Melilla o Málaga, pero también al Peñón de Vélez de la Gomera o Alhucemas. Todos los presidiarios salieron de Madrid conociendo su lugar de reclusión ya que, con la aprobación de la sentencia, el capitán general determinaba el lugar de cumplimiento. El destino de obras públicas fueron los caminos de Málaga o el muelle de Valencia.

La pena de azotes es impuesta en la sentencia, pero no es aplicada salvo en un caso. Bien el capitán general al aprobar la sentencia, bien alegando el indulto del monarca, la fustigación no se cumple. Tan sólo a Antonio Sánchez le fueron dados el doble centenar de azotes por haber abofeteado a un testigo, al entenderse como un desacato a la autoridad judicial ${ }^{48}$. En este caso, resulta manifiesta la absoluta discrecionalidad del tribunal en la determinación de esta pena.

Al tratarse de un castigo estrictamente militar se prohibió la imposición de la pena de baquetas a los paisanos por R.O. de 26 de junio de 1817. En esta y otras puniciones se diferenciaban las penas destinadas a los militares de las previstas para los paisanos.

\footnotetext{
48 «El escandaloso atentado cometido por Antonio Sánchez (Chorra al aire) de pegar una bofetada a un vecino de Algete en el acto de haberlo reconocido en rueda de presos en la real cárcel de corte, ha sido examinado en este Tribunal; y considerando no solo el desacato a la autoridad judicial, sino también en el mal exemplo que sería dexarle sin castigo por las desgraciadas consecuencias que ocasionaría para la averiguación de los delitos; el consejo ha sentenciado al expresado Antonio Sánchez a que sufra la pena de 200 azotes, sin perjuicio de las demás a que le hagan acreedor los crímenes por que se le está procesando; y aprobada por el Excmo. Sr. Capitán general dicha sentencia, ha sido executada en este día. Madrid 16 de noviembre de 1816» (DdM de 17.11.1816).
} 
Incluso, dentro de las primeras habría que distinguir entre las aplicables con carácter general y que no irrogaban infamia, de aquellas que sí lo hacían (horca). No obstante, también se podía agravar la modalidad de ejecución mediante el descuartizamiento posterior o desaforando al militar ${ }^{49}$.

La dureza de los consejos de guerra que juzgaban la delincuencia común se extendía, como resulta obvio, a la ejecución en particular la pena capita ${ }^{50}$. Para los militares el ser pasado por las armas no irrogaba infamia, por lo que esta forma de ejecución implicaba también para los paisanos juzgados por dichas comisiones el no sufrirla $^{51}$. El consejo de guerra de Castilla la Vieja conmutó a un reo el garrote por el

${ }^{49}$ El 30 de marzo de 1816 el brigadier Ángel de Ulloa comunicó a la Sala que, «haviéndose condenado por este consejo a Francisco Domingo Lucas, natural de Casasimarro, desertor del Reximiento de Usares españoles, a la pena de garrote, en 20 del presente mes, y haviendo sido aprobada esta sentencia por el Excmo. Sr. Capitán general de esta provincia en 27 del mismo, lo participo a V.S. con inclusión de copia literal de ella, para que disponga su execución, con acuerdo del fiscal de la causa, según lo prebenido por S.M. en la Real orden de 30 de junio del año próximo pasado. En cuya consecuencia, acabo de entregarme del reo, y queda puesto en capilla, para que sufra la pena impuesta el miércoles tres del corriente». A las 12.30 h. del día 3 de abril fue ejecutado. AHN, Consejos, libro 1406, exp. 164; y, libro 1407, exp. 66. En el primero se inserta copia de la R.O. de 30 de junio de 1815.

${ }^{50}$ «Habiéndose formado causa contra José Rodríguez, alias Paja larga, José de los Reyes y Francisco González... sobre varios robos en despoblado, han sido sentenciados por el consejo de guerra de la Comisión Militar, el Rodríguez, Paja larga, y Reyes a la pena de muerte en horca, y que cortadas sus cabezas se coloquen frente de la Hacienda de Torrequemada; y el González a la de seis años de presidio en Filipinas; cuya sentencia aprobó el Excelentísimo señor Capitán General y mandádose lleve a debido efecto, se notificó en este día, y se executará el sábado próximo a las once de su mañana en la plaza Real de San Fernando de esta ciudad; lo que se hace saber al público para escarmiento de los perversos, y que se convenzan de la suerte que irremisiblemente les espera si desde luego no abandonan su criminal ocupación, dedicándose como buenos al honroso trabajo en beneficio del Estado y propia utilidad», Diario crítico general de Sevilla de 30.03.1815. En el número del día anterior se anunciaba el consejo de guerra contra dos acusados de robos en despoblado.

${ }^{51}$ El capitán general de Castilla la Nueva expuso al rey en junio de 1815 que, debiéndose imponer por el consejo de guerra permanente «la pena de ser pasado por las armas, según la calidad de sus crímenes los reos paisanos o aprendidos por la tropa, y siendo dicha pena determinada por ordenanza para los delitos puramente militares, por cuya razón no irroga infamia en los que la sufran, pedía que comutase para los expresados reos paisanos en la ordinaria de garrote u horca según su clase». Tras el dictamen del Supremo Consejo de la Guerra se dispuso que «se observe en adelante por regla general que sin embargo de lo prevenido en la citada Real Cédula de 22 de agosto de 1814, la pena de muerte que los consejos permanentes establecidos en las capitales de provincias impongan a los paisanos por el delito de robos se conmute en la de garrote sea qual fuese la clase del sentenciado, para cuya execución será entregado por la jurisdicción militar a la justicia ordinaria, a fin de que mande y haga que se lleve a efecto dicha pena por egecutor público». Por ejemplo, AHN, Consejos, libro 1407, exp. 61, Oficio del corregidor interino dando aviso a la Sala de haberse entregado a la persona de Pedro Torrejón Monturque sentenciado por el consejo de guerra permanente a la pena de muerte (1816), con arreglo a la R.O. de 30 de junio de 1815 y ajusticiado en el garrote el 10 de enero de 1816. Ibídem, libro 1408, exp. 27, Oficio manifestando haberse entregado a las personas de Pasqual (García) alias Tapetado y Basilio Sánchez, sentenciados por el consejo de guerra permanente a la pena capital de garrote (1817). En la misma causa fue condenado Cirilo Ochoa a presenciar la ejecución y diez años de presidio, todos ellos «por salteadores de caminos en quadrilla con uso de armas». Fueron ejecutados el 20 de junio de 1817. DdM 
fusilamiento «por ser hijo de Valladolid, tener padres y mujer y no les fuese de tanta afrenta ${ }^{52}$. Para eliminar cualquier duda, en virtud de R.O. de 30 de junio de 1815, los paisanos condenados a muerte por estas comisiones serían ejecutados en garrote.

Con arreglo a dicha real orden, los reos civiles sentenciados a muerte por el consejo de guerra permanente de Castilla la Nueva eran entregados a la jurisdicción ordinaria madrileña para que los ajusticiara, de acuerdo con el fiscal militar. En julio de 1816 el presidente de dicho consejo comunicaba a la Sala de alcaldes de Corte la sentencia dictada contra Joaquín y Pedro Dombón y Mariano Carvajal «por ladrones y asesinos» a la pena de muerte por garrote ${ }^{53}$. El día 17, tras las comunicaciones habituales entre el tribunal militar y la justicia ordinaria para cumplir con la ejecución, fueron ajusticiados ${ }^{54}$. Esta relajación también se daba en las restantes penas ${ }^{55}$. No se producía dicha entrega, como es obvio, en el caso de ser pasado por las armas, aun cuando estuviera preso en una cárcel ordinaria ${ }^{56}$.

de 21.06.1817: «acusados de salteadores de caminos en cuadrilla con uso de armas, y reincidentes los dos primeros, por cuyos delitos anteriormente fueron sentenciados por la Chancillería de Granada, hallándose convictos de dichos crímenes, han sido condenados aquellos a la pena de muerte, y el último a la de diez años de presidio de África y cuya sentencia, aprobada por el Escmo. Sr. Capitán general de la provincia, ha sido egecutada en este día».

${ }^{52}$ Demetrio Martínez Martel y Abadía, Diario de Valladolid, Valladolid, 1885. Edición de la Biblioteca Virtual Cervantes.

${ }^{53}$ AHN, Consejos, libro 1.407, exp. 69.

${ }^{54} D d M$ de 18.07.1816: «Vista en este Tribunal la causa seguida contra Joaquín y Pedro Dombón, naturales de la Villa de Ricla, y Mariano Carvajal, de la de Épila, acusados de salteadores de caminos con muertes premeditadas, hallándolos convictos de dichos crímenes en las que executaron con robo a Pasqual y Mariano Ripollés, padre e hijo, y a Esteban Prades, su criado, fueron sentenciados a la pena de muerte; cuya sentencia aprobada por el Excmo. Sr. Capitán general de esta provincia, ha sido executada en este día. Tiemblen los malvados el fin que les aguarda, si no enmiendan su depravada vida, haciéndose útiles al Estado. Madrid, 17 de julio de 1816. Miguel Giró, secretario». En el oficio del corregidor a la Sala dando cuenta del enviado por el presidente del consejo de guerra se indica que fueron condenados a muerte «por ladrones y asesinos». Manifiesta que la justicia ordinaria debería hacerse cargo de los reos «desde el acto en que se verifique su notificación, y acordar todas las disposiciones necesarias hasta que hayan sufrido la pena capital, en inteligencia de que lo he contestado así al señor presidente del consejo permanente, manifestándole que será muy oportuno de que con anticipación pase el caballero fiscal u otro individuo de su tribunal a conferenciar con V.S sobre este asunto, según se ha acostumbrado en yguales casos para conciliar lo conviniente al modo y forma de su puntual cumplimiento» (AHN, Consejos, libro 1.407, exp. 69). El 17 de julio ante «un crecido número de gentes el executor de la Justicia Antonio Sastre, hizo su oficio con las personas de Joaquín y Pedro Dombón y Mariano Carbajal dándoles muerte en el garrote, donde quedaron según parece sin alientos vitales» (idem, libro 1.406, exp. 46). Fueron presos el 11 de octubre de 1814, «ignorándose el delito, aunque hay datos suficientes para creer que fue el de conspiración en sentido liberal», según Morales, Historia del Saladero, II, p. 297.

${ }^{55}$ AHN, Consejos, libro 1.407, exp. 70. Los no condenados a muerte lo estaban también a «presenciar la justicia». La ejecución se produjo el 22 de abril de 1816.

${ }^{56}$ «Deviéndose ejecutar en el día de mañana la sentencia pronunciada por el consejo permanente de guerra de esta provincia, aprovada por el Excmo. Sr. Capitán general de la misma, mediante la qual es condenado a ser pasado por las armas Francisco Auñón, soldado de la octava compañía del Regimiento de Úsares Españoles, quien se halla preso en las Reales Cárceles de Corte, he de merecer la benia de 
Las sentencias de muerte en garrote dictadas por los consejos ordinarios de guerra valencianos fueron corregidas en su ejecución desde finales de septiembre de 1819, pues aunque los paisanos estaban condenados a garrote «por las circunstancias de sus delitos... ha sido preciso conmutar la egecución y pasarles por las armas, porque se han ofrecido algunas dificultades para realizar la sentencia del consejo, aprobada por el Capitán general, y no convenía a la seguridad pública y la recta adminuistración de justicia suspender ni momentos los efectos del fallo que había recaído contra unos hombres que han ocasionado males de mucha consideración al Estado y a la humanidad $\rangle^{57}$. No constan las circunstancias reales del cambio, pero hay que tener presente que era preciso entregar los reos a la justicia ordinaria para que esta dispusiera el ritual de la ejecución. Quizá algún conflicto institucional entre la Sala del crimen y las autoridades militares desencandenó esta decisión. También el verdugo planteó inconvenientes y dilaciones. Esta disposición del capitán general se prolongó en el tiempo, pues a partir de esa fecha las condenas de garrote fueron sustituidas por el fusilamiento por la espalda ${ }^{58}$.

En la visita que León y Pizarro hizo a Valencia en 1818 podemos encontrar alguna descripción de lo que vio o le contaron: «había una comisión militar que, como siempre, se dirigía también contra los fascinerosos. El tribunal estaba en Murviedro. Se contaban mil cosas; pero del temor de ser apasionados debe excitar nuestra cautela; el hecho es que había ahorcados todos los días, todos como ladrones, aunque el susurro era otro. Yo vivía en casa del duque de Villahermosa, camino de estas ejecuciones, y era tal el disgusto que recibía, a pesar de cerrar las ventanas, que me mudé por esto. El verdugo era delicado, y decían que no tenía los sentimientos de su oficio, se ponía malo, etc.; de modo que, menudeándole los quehaceres, pedía misericordia; entonces se empezó a fusilar» ${ }^{59}$.

Sin entrar a valorar lo exagerado de este testimonio, sí es cierto, por la información publicada en el Diario de Valencia, que los consejos de guerra de dependientes del capitán general de Valencia impusieron un crecido número de penas de muerte, y en particular el ordinario de Sagunto. Además, si consideramos los datos proporcionalmente y los comparamos con otros similares de los tribunales ordinarios, la pena de muerte alcanza un elevadísimo porcentaje.

Si establemos la comparación entre los condenados a muerte por la Sala del crimen de la Audiencia de Valencia, donde no solo hay comisión de delitos patrimoniales

V.S. para pasar como fiscal de dicho consejo y causa a notificar la sentencia al reo expresado, y procedeer a lo demás, que en tal caso corresponde». 9 de febrero de 1815. AHN, Consejos, libro 1.405, exp. 142. ${ }^{57} D d V$ de 26.09.1819. Sobre el cambio en la modalidad de ejecución, Colón, Juzgados, III, pp. 164-167. ${ }^{58}$ Por ejemplo: «Mañana siete serán fusilados por la espalda, por no poder egecutarse la pena de garrote...», $D d V$ de 6.10.1819. Igual en $D d V$ de 9.10.1819, 5 y 15.11.1819, etc.

${ }^{59}$ Tomado de Javier Herrero, Los orígenes del pensamiento reaccionario, Madrid, 1988, p. 400. Sobre el atentado contra el general Elío en 1818 y la inmediata represión, que no paró con la ejecución de los trece principales acusados, existe abundante bibliografía. 
sino también contra la vida, con los ajusticiados por la jurisdicción militar; y, al mismo tiempo, realizamos el cotejo con las penas capitales dictadas por el consejo de guerra permanente de Castilla la Nueva y por la Sala de alcaldes de Casa y Corte, resulta el siguiente cuadro:

$\begin{array}{llllll}1814 & 1815 & 1816 & 1817 & 1818 & 1819\end{array}$

Sala del crimen de la Audiencia de Valencia Consejo de guerra de Valencia y Murcia Consejo de guerra de Castilla la Nueva Sala de alcaldes de Casa y Corte

Total de ajusticiados en Madrid

$\begin{array}{cccccc} & 9 & 7 & 18 & 6 & \\ 5 & 3 & 40 & 13 & 10 & 74^{60} \\ & 2 & 7^{61} & 4 & & 4 \\ & 9^{62} & & 7^{63} & & \\ 3 & 12 & 16 & 10^{64} & 4 & 9\end{array}$

Las escasas noticias del consejo de guerra permanente de Castilla la Vieja permiten atisbar que fueron pocos los reos ejecutados. Hasta el momento, solo hay constancia de cuatro sentencias y seis ajusticiados entre 1815 y $1817^{65}$.

En Madrid las ejecuciones de garrote se hacían la Plaza de la Cebada, mientras que los pasados por las armas lo eran a las afueras de la villa. Los consejos de guerra valencianos no solo ordenaron las ejecuciones en las poblaciones de su sede ${ }^{66}$, sino

${ }^{60}$ En este número se incluyen todos los condenados por el consejo de guerra de Sagunto, incluido un soldado acusado de reincidente en el crimen de sodomía.

${ }^{61}$ Tres fueron sentenciados a finales de 1815 y ejecutados en 1816.

${ }^{62}$ AHN, SACC, lib. 1406, f. 1317. Atribuyendo por error estos datos a 1816, de J.A. García Borrega, «Delito y sociedad en Madrid en el reinado de Fernando VII", Estudios de Historia Social, 20-21, 1982, pp. 227-290, en concreto p. 262.

${ }^{63}$ Discurso pronunciado en la Sala de señores alcaldes de Casa y Corte el día 2 de enero de 1818 por el señor gobernador de ella D. Domingo Fernández de Campomanes, Madrid, 1818.

${ }^{64}$ Historia del Saladero, II, pp. 302-305.

${ }^{65}$ Un tal Marianillo fue juzgado el 25 de abril de 1815 por «muertes atroces y muchos robos, escalamientos de cárceles en otros pueblos donde estuvo preso algunas veces, $\mathrm{y}$ aun en esta de la ciudad estuvo en pocos momentos hacer la fuga», y fusilado el 11 de mayo. El 28 de abril se celebró en la cárcel el consejo contra Caballo blanco y sus compañeros, siendo condenados el primero y dos más, presenciado la ejecución el cuarto; y fueron ejecutados junto a Marianillo. El 27 de mayo de 1816 fue ejecutado en el garrote y después descuartizado Manuel Hernández, el Cenizo, por «muchos robos y forzar mujeres... hacía sus salidas para cometer los delitos, y después se volvía a su casa con la mayor serenidad». El 18 dicho septiembre de 1817 fue fusilado Joaquín Collado, quien «había sido sentenciado por la Sala anteriormente a seis años de presidio, y no conformándose con dicha sentencia, pidió que le juzgase la tropa por haber sido sargento, y tomando la causa el consejo de guerra, halló haber sido desertor y pasádose al enemigo en tiempo de campaña con otros delitos», en Martínez Martel y Abadía, Diario de Valladolid.

${ }^{66}$ En la ciudad de Valencia los agarrotados lo fueron en la plaza del Mercado. Los fusilamientos se realizaron debajo del torreón de Santa Catalina, entre las puertas de San José y Cuarte; pero también en el rincón inmediato a la Real Aduana. En el caso de que hubiera paisanos y soldados involucrados en la misma causa y sentenciados a muerte, eran ajusticiados en sus respectivos lugares a la misma hora. 
también en otras localidades ${ }^{67}$. Durante 1819 el fuerte de Sagunto presenció un buen número de fusilamientos.

Los hechos delictivos por los cuales fueron condenados a muerte los trece reos sentenciados por el consejo de guerra de Castilla la Nueva, fueron los siguientes, por orden cronológico: Francisco Auñón por robo en camino real y muerte con premeditación, convicto y confeso; Julián Manrique, Seisdedos, por robos en cuadrilla y otros excesos, y haber hecho violencia a mujeres; Pedro Rodríguez Torrejón, Monturque, ladrón y salteador de caminos; Francisco Domínguez Lucas, por deserción, robo en casa de oficiales de más de 300 reales, salteador de caminos y otros excesos; José Escribano, Derecha, y Alfonso Domínguez, Lima, por ladrones, salteadores de caminos en cuadrilla, violencia a mujeres y resistencia a la tropa de que resultaron muertes; Joaquín Dombón, Pedro Dombón y Mariano Carvajal por salteadores de caminos con tres muertes premeditadas, hallándose convictos de dichos crímenes; Pascual García, Tapetado, y Cirilo Ochoa por salteadores de caminos en cuadrilla con uso de armas y reincidentes; Manuel Millán, por ladrón salteador de caminos; y, Antonio Sánchez, Chorra al aire, por ladrón salteador de caminos e indiciado gravemente en una muerte.

Las condenas capitales impuestas por el consejo de guerra permanente de los reinos de Valencia y Murcia y los ordinarios vinieron motivadas por unos hechos delictivos similares a los anteriores, aunque en ocasiones se empleara una desmedida violencia personal sobre las víctimas. Los números del Diario de Valencia en los que se da cuenta de las ejecuciones permiten comprobar la calificación que se les dio. Estos hechos tal y como figuran en dicho periódico son los siguientes, indicándose entre paréntesis el número de condenados a muerte. En 1814: crimen de robo con circunstancias agravantes (1); innumerables robos y otros excesos cometidos por desertores (2); e, inmuerables robos y otros excesos $(1,1)$. En 1815: robo con con llaves maestras (1); robo en despoblado con violencia (1); y, robo en despoblado y heridas causadas con alevosía y ventaja (1).

En 1816: muerte con ventajas (1); delitos de robo y asesinatos (2); reincidente en robo y uso de llaves (1); robos y delitos cometidos con la cuadrilla y por habre asesinado (1); robos con violencia en el camino real de Madrid (1); asesinatos y robos (1); salteador de caminos, desertor y otros excesos (1); robos, muertes y otros excesos en cuadrilla (4); compañero de una gavilla (1); robos y muerte (1); soldado reincidente en el brutal crimen de sodomía (1); robos, muertes y violencia a mujeres cometidos en cuadrilla (4); robos (4); robos en cuadrilla y muertes (1); robos, muertes y otros

${ }^{67}$ «En el pueblo de la Nucia se egecutó el día 17 del corriente la sentencia de garrote, impuesta por este tribunal...» a un total de cinco reos, $D d V$ de 2.08.1816. El 31 de agosto fueron ejecutados cuatros ladrones en Castellón, ídem de 6 de septiembre de 1816. «El día 21 sufrieron en el pueblo de Beniarrés la pena de muerte que les fue impuesta por este tribunal...», $D d V$ de 28.01.1818. En Alcoy constan tres ejecuciones el 5 de septiembre de 1816 . 
excesos (2); robo con violencia (1); robos en despoblado con violencia y uso de armas (1); haber muerto a un soldado (1); robos $(1,3)$; robos en cuadrilla (1); robo en camino real con uso de armas y resistencia a la tropa (4); y alevosía (1). En 1817: robos en despoblado con violencia y uso de armas (1); robos con fractura de puerta y violencia en otra (1); compañero de bandidos y concurrencia a robos (1); robos en cuadrilla, en uno de los cuales sentaron al dueño de una venta «por seis veces sobre el gran fuego que había en la cocina, con desnudez de la parte» $(5,1)$; robos en cuadrilla y asalto dado con fractura de la puerta de una casa (3); robos en cuadrilla, asalto dado con fractura de la puerta de una casa y «el crimen de haber violado en despoblado a una joven de 13 años» (1); y, resistencia a la tropa, comisión de varios robos y haber sido socio en un asesinato (1).

En 1818: desertores y resistencia a la tropa destinada a su aprehensión (2); robo en la casa-encomienda del infante don Carlos de la que se llevaron su caudal y el del gobernador (5); delitos de muertes, robos, saqueos, incedio, violencias, prostitución del templo, uso profano de los ornamentos del altar y de otros destinados al culto (1); socio en robos cometidos en cuadrilla (1); y, haber robado dinero del correo en cuadrilla (1). En 1819: robo en una venta de la Balsa, quema de su ventero y resistencia a la tropa (1); robo nocturno en una casa, cometiendo heridas, rompimiento de puertas, uso de armas y torpe violencia (10); robo en camino con violencia y uso de armas (2); robo nocturno en cuadrilla con violencia y uso de armas (4); robo en casa de una viuda con violencia, uso de armas y usando traje de militares algunos de los malhechores para lograr por este medio que la justicia no recelase de su objeto, habiendo herido al alcalde del pueblo de cuyas resultas murió (2); robos y asaltos a casas, cometidos con violencia y uso de armas (5); robo ejecutado en cuadrilla, con violencia y uso de armas, nocturno y simulando ser soldados (7); robo en una casa con violencia y uso de armas $(3,5)$; robo nocturno en una casa, con violencia, uso de armas y hacer fuego contra la justicia que acudió en auxilio del robado (3); cómplice en el robo de la diligencia de Valencia a Barcelona y «las circunstancias agravantes con que el reo contribuyó al atentado han obligado a que se le corte la cabeza» (1); robo en cuadrilla, con violencia y uso de armas, en una casa, por la noche y «cuyo dueño ha sufrido el ultraje de haberle atado los ladrones una soga al cuello colgándole de un hierro que había a la entrada de su casa, hasta el extremo de perder el sentido, habiéndose libertado de morir en fuerza de las suplicas de su madre» (8); robo ejecutado de madrugada con violencia y uso de armas en una casa situada en despoblado (4); robo ejecutado «con premeditación, violencia y uso de armas por la noche en casa de una viuda, habiendo insultado los ladrones al alcalde y aun robado después de verificado el principal» (6); robo verificado por la noche con violencia y uso de armas en casa de un sacerdote (7); robo verificado de noche en casa de una mujer con violencia y uso de armas (4); y, robos, muertes y otros excesos, complicados y condenados de ladrones salteadores de caminos y resistencia armada (2). 


\section{Conflictos jurisdiccionales}

Las actuaciones de las partidas militares contra esta delincuencia organizada y las condenas de los consejos de guerra permanentes durante 1815 y 1816 no surtían efecto. Con el fin de reorganizar la situación, por R.O. de 7 de marzo de 1817 quedó dispuesto que el Consejo consultara al monarca «si para conseguirlo sería conveniente establecer nuevas penas y coartar los términos, y dispensar formalidades en las causas contra semejantes delincuentes». Los fiscales del Consejo manifestaron que «las leyes comprendidas en el tít. 17, lib. 12 de la Novísima Recopilación, y la Real cédula expedida en 22 de agosto de 1814 contenían cuantas medidas pudiese excogitar la prudencia para la aprehensión y subsiguiente castigo de los ladrones de costumbre, salteadores de caminos, y otros malhechores públicos, que por lo mismo no había necesidad de nueva ley, y que lo que importaba era asegurar la observancia de aquellas por las justicias y autoridades militares con actividad y sin colusión ni disimulo». Así se expuso en consulta de 26 de marzo, con el fin de dar un «nuevo rumbo» para limitar esta delincuencia ${ }^{68}$.

Un hecho que favoreció la adopción de un cambio normativo se encuentra en la detención por un juez ordinario y, sobre todo, el enjuiciamiento por el consejo de guerra de Antonio Sánchez, Chorra al aire ${ }^{69}$, a pesar de que la Sala de alcaldes trató de imponer su jurisdicción ya que había sido capturado por la justicia ordinaria sin auxilio militar. Tan solo el traslado desde a la Corte correspondió a una partida militar, que fue la que puso al reo a disposición de la autoridad castrense, pues tenía pendiente una causa en el consejo de guerra «por cómplice en la muerte de un soldado del Regimiento de Dragones de la Reina y varios robos en la provincia de Guadalaxara», causa anterior a la persecución por los robos en la sierra. El 6 de julio de 1816 la Sala de alcaldes manifestaba que solo tenía noticia de la aprehensión del bandolero, lamentando que el alcalde de Quijorna no le hubiera dado cuenta «como deviera ni ésta se halla en el caso de entrar en contestación con el Capitán general, pues aun está pendiente la resolución de algunas consultas que tiene hechas en defensa de su privativa jurisdicción». Recriminó al juez su actuación conmonándole a que manifestara «qué motivos he tenido para no ponerle a disposición de la Sala ni dado cuenta a ese tribunal» ${ }^{70}$.

\footnotetext{
${ }^{68}$ R.C. de 10 de julio de 1817, en Gaceta de 7.08.1817.

${ }^{69} \mathrm{Su}$ captura fue complicada. Actuaba en la sierra madrileña, habitualmente solo. A comienzos de junio de 1816 había robado a varios hombres en los bosques de San Lorenzo, a pesar de ser «hombre de estatura menos que regular, y fornido, el qual decía se había escapado de presidio». Se afirmaba que «en estos lugares hace robos, y otros excesos, y en tanta conformidad que están todas las gentes aflijidas. El día de la Ascensión se nos avisó que estaba robando en la hermita de Santa Ana, jurisdicción de la villa de Pedrezuela...» Las justicias de los pueblos, auxiliadas por hombres armados, no podían aprehenderlo. Se destinaron varios destacamentos militares para conseguir su arresto (ibídem, libro 1.406, exp. 103). Fue ajusticiado en noviembre de 1817 junto con Manuel Millán por «ladrones salteadores de caminos» (ibidem, libro 1.409, exp. 43).

${ }^{70}$ AHN, Consejos, libro 1.406, exp. 103.
} 
Se estaba manifestando implícitamente un enfrentamiento larvado entre la jurisdicción ordinaria y la militar. A principios de abril de 1817 la Sala de alcaldes publicó una Circular para evitar los desordenes producidos por malhechores y cuadrillas de ladrones y bandidos que infestan los caminos, maltratando y robando a los pasajeros ${ }^{71}$. Es una disposición que afectaba solo al rastro de la Corte y auspiciaba, por un lado, la necesaria colaboración militar con las justicias ordinarias en la represión de la criminalidad; pero, por otro, la preeminencia de la justicia ordinaria en la substanciación y resolución de estas causas, obviando la jurisdicción militar. Con ella se trataba de delimitar la actuación de la autoridad militar y de los jueces y tribunales ordinarios, en la línea que se adoptará poco después. Sin perjuicio de que los interesados no tuvieran la certeza, o sí, de qué jurisdicción estaba procediendo. En este sentido, existieron intentos para desplazar causas iniciadas por los consejos de guerra hacia la justicia ordinaria o provocar algún conflicto jurisdiccional ${ }^{72}$.

Estos litigios no solo se originaban entre instituciones de la Corte, sino también fuera de ella. Los conflictos entre la jurisdicción militar con otras en la persecución, aprehensión y enjuiciamiento de bandidos y malhechores que delinquían en despoblado, también se dio con la Hermandad. Conflicto puntual que se resolvió a favor de ella a partir de lo establecido en disposiciones anteriores, concluyendo que la Real Cédula de 1814 «limita la autoridad de los consejos permanentes al conocimiento y determinación de las causas criminales contra los reos aprehendidos por la tropa en

\footnotetext{
${ }^{71}$ «Por repetidas providencias está mandado a todas las Justicias la persecución y castigo de los malhechores y cuadrillas de ladrones y bandidos que infestan los caminos, maltratando y robando a los pasageros; igualmente lo está, para evitar tales desórdenes, que cada una en su término ronde, zele y averigüe lo que ocurra, procediendo a la aprehensión de los delincuentes y gentes sospechosas, valiéndose en caso necesario del auxilio de la tropa destinada a este objeto, arreglándose para ello a las órdenes e instrucciones comunicadas, y avisando sin dilación a la Sala de cualquiera ocurrencia. En el día se han hecho demasiado frecuentes estos insultos en las inmediaciones de la Corte, sin embargo de las partidas de tropa que están acantonadas en los pueblos de... Para evitar que en lo sucesivo se repitan se ha formado por el Excmo. Sr. Capitán general de esta Provincia una instrucción para los comandantes de dichas partidas, y otra para las justicias de los pueblos, a fin de que procediendo de común acuerdo unos y otros pueda hacerse mejor este servicio; de que enterada la Sala ha acordado se prevenga a V. de su orden "ponga en egecución cuantas reglas están dictadas para semejantes casos, redoblando su zelo en el reconocimiento de los caminos, mesones, ventorrillos y parages sospechosos, procediendo a la prisión de las gentes que lo sean, formándoles causas, y dando luego cuenta a la Sala por mano del Sr. Fiscal; en inteligencia de que de cualquiera omisión o disimulo que se notare en su término se hace a V. responsable, y se tomará la providencia que corresponda"» (Gaceta de 3.04.1817).

${ }^{72}$ En octubre de 1816 Jacinta Sáenz, mujer de Raimundo González acusado de «cómplice en diferentes robos», solicitó el indulto de la pena que le correspondiera o que se determinara pronto su causa. La Sala de alcaldes manifestó que estaba «preso en la cárzel de Corte a disposición del consejo de guerra permanente en donde pende su causa y por lo mismo no ha podido la Sala en cumplimiento de dicha Real orden tomar la providencia conveniente, haviendo solo podido averiguar que el citado Raymundo González con un consorte llamado Pedro Guijarro se hallan presos desde el 20 de abril de 1815». AHN, Consejos, libro 1.406, exp. 94. González fue condenado a seis años de presidio en África y Guijarro a dos de obras públicas en Málaga por robos ( $D d M$ de 7.01.1817).
} 
caminos y despoblados sin concurrencia principal de las justicias ordinarias; mas cuando estas obran por sí, aunque auxiliadas de la fuerza armada, las funciones de esta son secundarias y dependientes en su modo, lo que no atribuye derecho de proceder ${ }^{73}$.

En este marco hay que encuadrar la Real Cédula de 10 de julio de 1817 por la cual se establecieron nuevas reglas para la aprehensión y castigo de malhechores, evitar que se repitieran sus violencias y robos, y afianzar la tranquilidad y seguridad pública $^{74}$. Se pretendía una mayor colaboración entre las tropas destinadas a la persecución de malhechores y las autoridades judiciales, relevando de su conocimiento a los consejos de guerra establecidos en las provincias, salvo cuando se resistieran con las armas a su aprehensión, con lo cual se reducía el ámbito personal de estos consejos. En concreto, se relevó «a los consejos de guerra establecidos en las provincias de la formación de procesos y causas a los reos que las tropas aprehendieren en el campo o en poblado, exceptuando los casos en que aquellos hicieren fuego o resistencia con arma blanca, según y como se dispuso en los artículos 8, 9 y 10 de la Instrucción de 29 de junio de 1784, a los que deberán quedar ajustados los 5, 6, 7 y 10 del Reglamento inserto a continuación de la primera en la Real cédula de 22 de agosto de 1814» (art. 4). Por tanto, se mantenía el privilegio jurisdiccional para los militares, pero se separaba la competencia entre jurisdicciones por la resistencia armada a la partida militar. Reservándose las autoridades de la Corte el conocer periódicamente cuanto se avanzara y resolviera en estos asuntos ${ }^{75}$.

${ }^{73}$ Circular del Consejo de 30.04.1817. El problema se desencadenó cuando un comisionado de la Hermandad vieja de Toledo para la persecución y aprehensión de ladrones y malhechores que infestaban los caminos, detuvo a uno y en prisión delató a sus compañeros. Para su arresto pidió auxilio al comandante militar de Toledo, que le franqueó la fuerza. Aprehendidos cinco malhechores, dicha autoridad «previno al comisario cuadrillero los pusiese a su disposición con las caballerías y efectos que se les habían cogido, y que hiciese entrega de ellos al oficial con quien dirigía la orden». El comisionado se negó a ello sin autorización del alcalde de la Hermandad, por lo que fue apremiado por el militar. El alcalde de la Hermandad lo puso en conocimiento del rey, señalando «que el fundamento de querer sujetar los reos a la jurisdicción militar y consejo permanente consistía en lo prevenido en Real Cédula de 22 de agosto de 1814, pero que era caso muy diverso el del día, por cuanto la tropa había obrado no como principal, sino auxiliando a un juez ordinario, y en virtud de citación de los reos que se hallaban en la cárcel de la Hermandad sin intervención del comandante militar», reclamando también sus privilegios jurisdiccionales y que la causa quedara bajo su autoridad. El rey se conformó con la consulta del Consejo Real, disponiendo que «el conocimiento de la causa criminal de que va hecha relación compete al alcalde de la Santa Hermandad de Toledo, como todas las de su clase», en AHN, Consejos, libro 1.409, exp. 186.

${ }^{74}$ Gaceta de 7.08.1817.

${ }^{75}$ Art. 9: «Los Capitanes generales y los Acuerdos de las Chancillerías y Audiencias darán parte indefectiblemente al mi Consejo... de lo que se egecute y adelante en la aprehensión de foragidos, en la formación de sus causas, y en el restablecimiento de la seguridad de los pueblos y caminos; expresando los Capitanes generales los reos aprehendidos por la tropa, y el día, parage y motivo de la prisión; y los Acuerdos lo harán también de las causas pendientes, sugetos presos o comprendidos en ellas, su delito, día en que empezaron, y estado que tengan; noticiándose igualmente en los mismos partes o con separación, los robos y excesos que se cometan en sus distritos, con designación del pueblo a que corresponda el territorio en que se verifiquen, para que con estas noticias puntuales, y el conocimiento de los casos 
La consecuencia en la restricción de la competencia jurisdiccional militar era que los ladrones y malhechores capturados por la tropa serían inmediatamente puestos a disposición de las Salas del crimen de las Chancillerías y Audiencias, «por las cuales deberán ser procesados, juzgados y castigados conforme a las leyes del reino, a excepción únicamente de los reos militares, los cuales quedarán exentos de la sujeción a la jurisdicción ordinaria» (art. 5). No obstante, para facilitar un rápido castigo, dichos tribunales «en la formación de los procesos de esta clase omitirán cualesquiera diligencias excusables que no fueren necesarias o muy convenientes para la completa averiguación de los hechos sustanciales, en cuanto al delito y sus perpetradores, cómplices y auxiliantes, y estando las causas en estado de plenario se estrecharán los términos para su conclusión y sentencia, concediendo los puramente precisos para que los reos puedan probar las exenciones legales que no estuvieren bastantemente acreditadas en el sumario» (art. 6). Con el fin de evitar la benignidad de los tribunales ordinarios y como manifestación del legalismo absolutista, el art. 7 prohibía rebajar las condenas capitales en los casos legalmente previstos, es decir, «para los delitos de robo calificado, la impondrán forzosamente a los reos sin arbitrio a conmutarla en otra alguna, supuesta, la prueba legal competente, como así está prevenido por la ley 10, tít. 2, lib. 3 de la Novísima Recopilación». De modo que para conseguir los objetivos regios, «se restablecerá el orden y modo de preceder contra los bandidos y salteadores que anduvieren en cuadrilla, determinado y prescrito por la ley 1, tít. 17, lib. 12 del mismo código, la cual deberá ponerse en plena egecución y observancia por los tribunales y justicias en sus respectivos territorios, procediendo con toda actividad» (art. 8).

Con fecha 26 de agosto de 1817 el Secretario de Estado y del Despacho de la Guerra se dirigía a los capitanes generales mediante una orden en la que manifestaba que el rey «ha resuelto que se suspendan los efectos de la Real cédula de 10 de julio última expedida por el Consejo de Castilla, por la cual se establecían reglas para la aprehensión y castigo de malhechores hasta nueva determinación». El conflicto institucional subyacente había estallado. Las autoridades militares enfrentadas al propio Consejo Real habían conseguido, de momento, una victoria al paralizar la preferencia de la jurisdicción ordinaria, salvo en los casos detallados.

Fue preciso esperar a una posterior disposición del Secretario de Estado de Gracia y Justicia para conocer un nuevo resultado de este enfrentamiento. El 2 de diciembre de 1817 dirigía a las Capitanías generales una nueva real orden que tenía como apoyo el informe elaborado por cuatro ministros del Consejo supremo de Guerra y otros tantos del Consejo de Castilla, mandado redactar tras la suspensión ordenada el 26 de agosto de la Real cédula de 10 de julio. Fernando VII se inclinó por el lado cas-

particulares que ocurran, pueda el mi Consejo acordar las providencias conducentes a que alcance su autoridad, o consultarme lo que fuere necesario; y las mismas autoridades enviarán directamente un egemplar conforme de estos partes a mi Secretario del Despacho de Gracia y Justicia». 
trense, teniendo igualmente presente las razones que habían movido a su abuelo y a su padre a dictar la Instrucción de 1784 y las Reales órdenes de 30 de marzo de 1801 y 10 de abril de 1802, por las que se atribuía «a la jurisdicción militar el conocimiento de las causas de todos los referidos reos aprehendidos por la tropa aun cuando no formalizasen resistencia; y como las circunstancias pasadas aumentaron el número de malhechores y crecieron extraordinariamente los males que causan, decidieron su Real ánimo a sancionar la Real cédula de 22 de agosto de 1814 que expidió el referido Consejo Real para el pronto castigo de los muchos bandidos que infestaban los caminos y poblaciones, cometiendo los más atroces atentados; pero no habiendo cesado del todo dichos males a pesar de los buenos resultados que ha producido dicha Real cédula, y queriendo S.M. que se consiga el total exterminio de los bandidos para que sus amados vasallos disfruten de la seguridad que desea su paternal corazón, se ha servido resolver, que se observe la Real cédula de 22 de agosto de 1814 expedida por el Consejo de Castilla para la persecución de los malhechores, ínterin S.M. resuelve sobre el trabajo que con este objeto está haciendo el Consejo supremo de la Guerra... quedando sin efecto alguno la de 10 de julio del presente año publicada por el mismo tribunal $»^{76}$. La balanza se inclinaba ahora del lado militar.

En cualquier caso, ni la dura represión militar directa, ni la actuación de los consejos de guerra, ni la que correspondía a la justicia ordinaria lograron mitigar la criminalidad patrimonial de la posguerra. A esta situación hay que añadir que desde el estamento militar se lamentaba que las justicias ordinarias no castigaran con el rigor legal. Estas circunstancias son las que movieron al capitán general de Andalucía a dictar un bando, en el que se aprecia la absoluta discrecionalidad militar, se ponían de manifiesto estas deficiencias y se trataba de atajar cualquier atisbo de mitigación punitiva:

«He observado con sentimiento que nada basta a contener al delinquente, abandonado a sus vicios, mira con indiferencia o desprecio las leyes divinas y humanas, sino la imposición y execución de las penas establecidas por las mismas leyes. Ni la amenaza, ni el apercibimiento, ni la equidad sacan frutos de tales hombres, que mas parecen fieras, pues de ellos no están seguras ni las vidas, ni las haciendas de sus semejantes. Aunque la multitud de robos, y raterías que se experimentaban en esta ciudad, me movió a publicar en $1^{\circ}$ de febrero del año pasado de 1816 el bando que es notorio, imponiendo con arreglo a la ley de Partida la pena de 200 azotes a todo ladrón ${ }^{77}$, sin perjuicio de la causa y de agravarle hasta la capital según la clase del hurto, y entonces vi contenido este exceso; advierto con dolor que se ha vuelto a continuar con el mayor descaro tal crimen, quebrantándose rexas, arrancando escalones, y cometiéndose otras violencias, sin duda porque los viles perpetradores de tan feos delitos fundan la esperanza de su indemnidad en los trámites dilatados de los juicios que a veces son causa de que no se les prueben

\footnotetext{
${ }^{76} D d V$ de 25.12.1817. Las referencias a las consultas del Consejo de 22 de abril de 1818,18 de enero y 28 de julio de 1819 solicitando el levantamiento de la suspensión de la R.O. de 10 de julio de 1817, en Actas del Consejo de Ministros (1828), Madrid, 1990, p. 57, sesión de 23 de febrero de 1828.

${ }^{77}$ Remisión a P. 7, 14,18. La ley alfonsina, sin embargo, estaba modificada por otras recopiladas.
} 
con toda la formalidad debida. Este inconveniente es el que las leyes y Reales ordenes han querido evitar en aquellos crímenes, que por su gravedad merecen un pronto y exemplar castigo; de aquí la Real instrucción y órdenes Reales para que los bandidos y malhechores sean procesados militarmente; de aquí otras Soberanas disposiciones... Declaro nuevamente que el ladrón será castigado con la pena de 200 azotes y ocho años de presidio en África, según, y en los términos que lo determiné en el citado bando de $1^{\circ}$ de febrero. Y para quitar a la expresada clase de delinqüentes la esperanza de la dilación, declaro también, que siguiendo el espíritu de las referidas leyes y Reales órdenes, serán juzgados breve y sumariamente en el orden militar; cuyo sistema seguiré igualmente con los vagos, jugadores, viciosos, y mal entretenidos, que son los más proporcionados para toda clase de delitos, a fin de que desaparezca de una vez esta raza tan odiosa, tan criminal y tan perjudicial al Reino y sus habitantes. Y para que llegue a noticia de todos, ninguno alegue ignorancia, y sepan que, a pesar de los sentimientos de mi corazón, seré inexorable en el castigo del robo» ${ }^{78}$.

A partir de 1818 apenas volvemos a tener noticias del consejo de guerra permanente de Castilla la Nueva, aunque sí de la actuación del consejo de guerra de oficiales generales que, en la mayoría de los casos, actúa contra soldados y oficiales que han cometido muertes violentas y robos, por lo cual han abandonado su destino. También procedió en 1818 contra el paisano Lorenzo Aragón, José Muñoz, alias el Bobero, y otros reos por «robos, muertes y otros varios excesos». Los reos consiguieron ausentarse de Madrid y evadirse momentáneamente de la justicia militar ${ }^{79}$. Pronto fueron apresados, siendo sentenciados en junio de $1819^{80}$. La sentencia, fallada por unanimidad, «en atención a resultar convencidos por pruebas indubitables y claras de robo en Corte, caminos reales y en cuadrilla, con reincidencia continuada en estos crímenes y muerte al tiempo de la egecución de ellos», condenó -a la vista de las mentadas causas de agravación de la pena- a muerte de horca conmutada por la de garrote, de acuerdo con la R.O. de 30 de julio de 1815, a los dos mencionados -si bien Lorenzo Aragón se hallaba ausente y rebelde-, a José Moreno, alias el Chulo, y Manuel Royo. A otros dos reos en diez años de presidio, si bien contra uno de ellos se seguía otra causa ante la jurisdicción ordinaria por una muerte violenta y heridas. A otro ladrón, cuatro años de presidio «por la misma complicidad», sin perjuicio de otra que se le seguía por otra muerte violenta. Dos soldados fueron remitidos a sus cuerpos, apercibidos y sin perjuicio de ser juzgados por los demás delitos. Las dos mujeres encau-

\footnotetext{
${ }^{78}$ Diario Mercantil de Cádiz de 18.03.1817. Bando del marqués de Castelldosrius de 17.03.1817. Más extenso y pormenorizado es el bando militar de Javier Elío de 26.05.1816 publicado en $D d V$ de 25.06.1816

${ }^{79} D d M$ de 17.07.1818.

${ }^{80} D d M$ de 23.06.1819, donde se inserta completa la sentencia del consejo de guerra ordinario. José Muñoz, el Bolero, fue preso el 28 de setiembre de 1817; José Moreno, el Chulo, el 13 de mayo de 1819; y Manuel Royo el 20 de junio de 1819. Fueron procesados «por haber derribado una estatua de piedra que estaba en la fuente de Perales de Tajuña, e incendiado dos cabañas de guardas, por cuyos delitos fueron indultados, ignorándose el que cometerían después para ser condenados a muerte en garrote, cuya pena sufrieron el 23 de junio de 1819» (Morales, Historia del Saladero, II, pp. 330-331).
} 
sadas «por sus auxilios prestados a algunos de los reos anteriores sean destinadas a seis años de reclusión en la Real casa galera u otra», apercibidas en lo sucesivo, y una más «por iguales motivos y en los mismos términos sufra la propia pena por espacio de cuatro años».

La R.C. de 4 de marzo de 1819 declaró abolidos los consejos de guerra creados antes y después de la R.O. de 6 de septiembre de 1814, dejando solo subsistentes los recogidos en las Ordenanzas militares, pero también el ordinario de oficiales para enjuiciar a los malhechores ${ }^{81}$. Este último tenía una doble jurisdicción: la castrense, propia; y la ordinaria criminal para causas en las que se hubiera hecho resistencia armada a la tropa, que es la acumulada. Los consejos de guerra permanentes cesaron, pero la represión la asumieron los ordinarios, incluso con mayor dureza.

Los últimos meses de 1819 fueron especialmente activos para la jurisdicción militar de Valencia. Meses en los que funcionó enérgicamente el consejo de guerra en Sagunto para juzgar a los malhechores que infestaban las tierras valencianas, aunque la dura represión política de Elío tras su frustrado homicidio también debió de estar presente $^{82}$.

El 11 de agosto insertaba el capitán general en el Diario de Valencia una larga nota dando cuenta de que en varias causas incoadas por la Capitanía aparecían tres acusados de «varios robos, muertes y otros excesos, resultaban complicados y condenados de ladrones salteadores de caminos y aun de muchos atentados». Habían

${ }^{81}$ La R.O. de 2 de agosto de 1815 requería al Consejo supremo de la Guerra para que elevara al rey «una relación circunstanciada de todos los tribunales militares inferiores establecidos en la península desde el principio de la revolución y después de la venida de S. M., tales como los consejos permanentes y comisiones creadas por la Real orden de 6 de setiembre de 1814», con expresión de sus componentes, atribuciones y objeto de su instituto. En otra de 4 de febrero de 1816, por la que se extinguía el consejo de generales del Puerto de Santa María, se dispuso «que de nuevo le consultase el Consejo sí será conveniente la extinción de los demás consejos permanentes en las provincias». El citado Consejo pidió a los capitanes generales noticia exacta de los tribunales militares de su provincia. Con lo que aquellos expusieron, el Consejo elevó al rey el 31 de octubre de 1818 su consulta, de la cual trae consecuencia la R.R. de 22 de febrero de 1819. El art. 2 de la cédula de marzo estableció: «Que permanezcan solo los consejos que señala la Ordenanza general del Ejército, la de los regimientos de Guardias de Infantería, y la Real orden de 18 de abril de 1799, que son: el de Generales para las causas de los oficiales en delitos militares, el cual ha de conocer también de aquellas en que entendía la comisión militar que se estableció en todas las Capitanías generales por la Real orden de 6 de setiembre de 1814; el consejo ordinario de oficiales para los delitos de la tropa, y las causas de malhechores de que trata la Real cédula de 22 de agosto de 1814; y el consejo extraordinario para los sargentos, cabos y soldados graduados de oficiales; que en la formación de los procesos, nombramiento de vocales y modo de dar sus votos se observe exactamente lo prevenido en la Ordenanza».

${ }^{82}$ Este consejo ordinario funcionó entre 1815 y 1819: «D. Anastasio Navas, abogado y capitán de artillería graduado de comandante, fiscal militar que había sido del consejo de guerra que, durante el mando de Elío, desde 1815 a 1819, funcionaba en Sagunto y de cuyas sentencias y opiniones hablaban los periódicos liberales, lo que dio motivo a Navas para salir a la defensa del Consejo de que formó parte, publicando unas hojas sueltas bajo el título de Cartas de la abuela a la nieta, y de esta a la otra», Luis Tramoyeres Blasco, «Periódicos de Valencia», Revista de Valencia, 1, 1881, p. 515. 
sido perseguidos infructuosamente, hasta que reunidos en una barraca de la Albufera «para ejecutar un robo en aquella misma noche con otros varios malhechores», fueron sorprendidos por una partida de fusileros. Rodeados, hicieron fuego contra la tropa, cuyo mando ordenó quemarla para que salieran, si bien «la resistencia de estos monstruos fue proporcionada a sus crímenes». Uno de ellos fue muerto y los otros dos capturados, aunque uno herido. En la refriega murió un miñón y dos resultaron heridos. Ante estos hechos, Elío ordenó que se les formase inmediatamente el proceso y se les juzgase. Capturados el día 4 de agosto fueron ahorcados una semana después los dos que sobrevivieron, «y para que no se liberte la memoria de Cervera de la infamia de la condena que no puede sufrir, se le ha incluido en la sentencia». Desde luego que la autoridad militar optó por una modalidad de ajusticiamiento apenas utilizada por ella, sin duda para agravar aun más el suplicio y añadirle la nota de la infamia. Asimismo, Javier Elío se vanagloriaba del fin de estos malhechores y de que la mayor parte de sus compañeros estaban descubiertos y presos, y anunciaba que en pocos meses irían desapareciendo «todos los enemigos del orden y de la sociedad», pudiendo «el valenciano honrado vivir tranquilo en su casa en el seno de su familia, y el caminante andar sin la misma zozobra que ahora» ${ }^{83}$. También invitó a los valencianos para que delataran a otros malhechores, «seguros de no tener nada que temer de ellos», prevención que debía de estar muy presente en muchos individuos, sobre todo, de las zonas más despobladas. Fundamentaba su petición en que «todas las leyes divinas y humanas autorizan a perseguir a esta raza de asesinos, ladrones y atentadores a la autoridad del Rey, y de un pueblo cristiano y civilizado.... ${ }^{84}$. La idea es poner de manifiesto a los valencianos que, gracias a la jurisdicción militar, se estaba consiguiendo la represión de la criminalidad que atemorizaba al reino ${ }^{85}$. Quizá por contraposición a la habitualmente más benévola justicia ordinaria, amparada en una secular tradición jurídica, y no sometida a la obediencia estricta de las órdenes superiores.

Ese interés en la rápida resolución de los procesos y en su inmediata ejecución, queda palpable en la actuación del consejo de guerra de la plaza de Sagunto que, continuando «el descubrimiento de los horrorosos atentados cometidos por los muchos

\footnotetext{
${ }^{83}$ En la noticia de las ejecuciones del 7 de octubre señalaba que «la muerte de estos malvados, confesos algunos, y otros convictos de sus crímenes, asegura a los habitantes de estos Reinos la tranquilidad de sus hogares que con tanto escándalo ha sido interrumpida hasta el día; y yo espero que el castigo de tales monstruos, y el que se imponga a los que quedan presos en la referida plaza, contra quines se siguen causas con la mayor actividad, se extingan los desórdenes que por todas partes afligían a los honrados vecinos y traficantes, atacados continuamente en sus casas y caminos, cuya desgraciada suerte lloran todavía algunas familias», $D d V$ de 6.10.1819. En términos similares, $D d V$ de 9.10.1819.

${ }^{84} \mathrm{DdV}$ de 11.08.1819.

${ }^{85}$ En $D d V$ de 15.11.1819 se lee: «El público que ve la actividad con que la jurisdicción militar le proporciona el castigo de semejantes monstruos, hallará en esto el interés con que procura la tranquilidad y seguridad pública que yo me prometo conseguir enteramente en el distrito de mi mando a beneficio de estos egemplares de justicia, contra los que tan escandalosamente se habían empeñado en perturbar el buen orden».
} 
malhechores presos en dicha plaza, de cuyos hechos se presentan las más convincentes pruebas», se concluyó la causa contra cinco reos y quedaron sentenciados a garrote sustituido por el fusilamiento. No obstante, «habían cometido otros muchos crímenes, pero como las pruebas de los dos citados han producido el resultado más completo para condenarles por ellos, se ha omitido proceder sobre los demás para adelantar el pronto castigo que exigía la crítica situación a que semejantes bandidos habían reducido el reino» ${ }^{86}$. Esta determinación provocó que algunos miembros de la misma cuadrilla fueran ejecutados, por los mismos o diferentes hechos, en fechas distintas ${ }^{87}$.

La noticia más impactante de la dureza con la que actuaba la jurisdicción militar en tierras valencianas la encontramos en el Diario de Valencia de 15 de octubre de 1819:

«Veinte y tres malhechores de los condenados a pena capital en el Fuerte de Sagunto por la Jurisdicción militar, han sido fusilados con pocos días de intermisión, y se han impuesto destino de presidio a otros, que complicados en las mismas causas tenían en su apoyo la falta de justificación tan completa, como exigen las leyes para la imposición del último suplicio. Hoy sufrirán esta pena... todos los que hasta el día han sido juzgados tenían contra sí una multitud de excesos, habiéndose elegido el medio de procesarles por uno solo cuando había suficiente justificación, procurando por este medio el pronto castigo de los malos para satisfacción de la vindicta pública».

De los cuatro ajusticiados en Madrid durante 1820, dos de ellos fueron condenados a muerte por el consejo de guerra de Castilla la Nueva, procesados por delitos de rapto, estupro, robos y resistencia armada a la autoridad. Fueron fusilados el 5 de enero de $1820^{88}$. En Valencia, algunos salvaron la vida al proclamarse el día fijado para su ajusticiamiento la Constitución de $1812^{89}$.

Estas medidas del Sexenio absolutista, con los precedentes normativos de los reinados de Carlos III y su hijo, se trasladarían al primer bienio posterior a la caída del régimen constitucional en 1823, e incluso a los últimos años de vida de Fernando VII. El monarca se sirvió también de los tribunales militares para la represión política. La R.O. de 13 de enero de 1824, cuya vigencia se preveía circunstancial según su art. 18, creaba en todas las capitales de provincia una comisión militar ejecutiva y permanente ${ }^{90}$. Estas comisiones reprimieron con dureza tanto la delincuencia de las

\footnotetext{
${ }^{86} \mathrm{DdV}$ de 9.10.1819.

${ }^{87}$ Por ejemplo, $D d V$ de 5 y 15.11 .1819 y 17 y 22.12 .1819 .

${ }^{88}$ Estos dos soldados eran Antonio Castañeira y Ramón Anglés, de 21 y 32 años respectivamente (Morales, Historia del Saladero, II, p. 350). Habían sido apresados el 31 de diciembre de 1819.

${ }^{89} \mathrm{El}$ consejo de guerra ordinario de Alcoi sentenció en marzo de 1820 a un grupo de malhechores entre los que había paisanos y un desertor a la pena de muerte por hechos ocurridos en 1817, pena que debía ejecutarse los días 9 y 10 de marzo de 1820, pero este día se promulgó la Constitución gaditana. Arcos, La senda dels lladres, pp. 83-84. El 9 de febrero de 1820 otros cuatro habían sido pasados por las armas (idem, p. 82).

${ }^{90}$ Sobre las creadas, aunque no de todas ellas se tiene noticia de su actuación, Pegenaute, Represión, p. 45. Sin olvidar las críticas a la postura anterior de Josep Fontana, «Represión política y violencia civil
} 
gavillas como la política. La actuación de una de estas comisiones, la de Castilla la Nueva, fue especialmente dura, propagándose a todas ellas algunas de los aspectos más represivos que no pueden generalizarse sin matices a las restantes. No todos los que pasaron por ellas fueron condenados a muerte, pues hubo de todo, aunque el mero hecho de ser juzgado por una de estas comisiones ya era de por sí castigo suficiente por todas las adherencias que conllevaba esa marca.

\section{A modo de conclusión}

La jurisdicción militar, que había asumido una actuación importante para el mantenimiento del orden público desde el reinado de Carlos III, renovó su actuación transcendente contra la delincuencia patrimonial a partir de 1814. Los consejos de guerra permanentes creados en toda España enjuiciaron, con arreglo a las disposiciones militares, la comisión de delitos patrimoniales cuando los reos hubieran sido perseguidos por tropas, por decisión de la autoridad militar, o hubieran hecho resistencia armada a la misma. No obstante, existen diferencias notables entre ellos en cuanto al rigor con el que actuaron, advirtiéndose sus diferencias por la personalidad del capitán general al que estaban sometidos. También fueron relevantes los conflictos, manifiestos o larvados, entre las jurisdicciones militar y ordinaria por el enjuiciamiento de ladrones o bandoleros, lo que obligó a dictar disposiciones para abordar el alcance y limitaciones de cada una de ellas.

Con la experiencia adquirida durante el Sexenio, el sistema se perfeccionará con mayor dureza durante la Década Ominosa a través de las comisiones militares.

en 1823-1833: propuestas para una interpretación», en Industrialización y nacionalismo (I Coloquio vasco-catalán de Historia), Barcelona, Universidad Autónoma, 1985, pp. 313-327; y La crisis del antiguo régimen, 1808-1833, Barcelona, Crítica, 1979, p. 172. 